\title{
Novos Dados G eológicos e G eofísicos para a Caracterização Geométrica e Estratigráfica da Sub-bacia de Alhandra (Sudeste da Paraíba)
}

\author{
New G eological and Geophysical Data for the Geometric and Stratigraphic \\ Characterization of the Alhandra Sub-basin (Southeast of Paraíba)
}

Benjamim Bley de Brito Neves (bbleybn@usp.br), José do Patrocínio Tomaz Albuquerque² (patrociniotomaz@uol.com.br), José Moacyr Vianna Coutinhoํㅜ (mlcout@ osite.com.br), Francisco Hilário Rego Bezerra ${ }^{3}$ (bezerrafh@ geologia.ufrn.br)

${ }^{1}$ Departamento de Mineralogia e G eotectônica - Instituto de Geociências - USP

R. do Lago 562, CEP 05508-080, São Paulo, SP, BR

${ }^{2}$ Departamento de Engenharia Civil - UFCG, Campina Grande, PB, BR

${ }^{3}$ Departamento de Geologia - UFRG N, Natal, RN, BR

Recebido em 02 de dezembro de 2008; aceito em 10 de maio de 2009

\section{RESUMO}

Alguns estudos recentes geológicos e geofísicos foram realizados na Sub-bacia de Alhandra (segmento sul da Bacia Paraíba) e revelaram comportamentos estratigráfico e estrutural interessantes, que não haviam sido discriminados anteriormente. Quatro diferentes compartimentos (com trende NNE-SSW) foram identificados, cada um deles caracterizado por uma pilha estratigráfica peculiar, como o resultado de deslocamentos verticais, provavelmente posteriores ao Plioceno: o "Alto Estrutural” do alto curso do Rio Mumbaba (com muitas exposições do embasamento cristalino), o graben do Rio Mamuaba (onde a Formação Beberibe aflora extensivamente), o “Alto Estrutural” do Rio Gramame (zona de horste, com alguns afloramentos do embasamento, subjacente à formação Beberibe) e a "Zona Estrutural” do monoclinal Alhandra-Guruji-Conde-Caaporã, que fica a leste da BR-101, e que é limitado por uma linha de falha, na sua borda ocidental. A sequência estratigráfica da Bacia do Paraíba (Grupo Paraíba) está completa apenas ao longo da porção oriental da estrutura monoclinal, onde adicionalmente as ocorrências do Grupo Barreiras conseguiram ficar preservadas. Ao longo do graben do Rio Mamuaba, ocorrências do Grupo Barreiras não foram detectadas (como seria esperável), o que parece ser uma indicação para a ocorrência de mais de uma fase de movimentos verticais, um dos quais provavelmente varreu o Grupo Barreiras desta área. Todas estas observações são preliminares e demandam estudos posteriores geológicos e geofísicos, especialmente aqueles em escalas superiores a 1/50.000.

Palavras-chave: Bacia Pernambuco-Paraíba; Cretáceo; Alhandra; Formação Beberibe; Margem continental atlântica.

\begin{abstract}
Some recent geological and geophysical reconnaissance studies carried out in the Alhandra Sub-basin (southern segment of the Paraíba Basin) have revealed very interesting structural and stratigraphic behaviors that have not yet been described. Four different structural compartments with NNE-SSW trends were identified, each characterized by a particular stratigraphic pile, as a result of vertical tectonic displacements, probably post-Pliocene in age: the Alto Rio Mumbaba High (with widespread basement outcrops), the Rio Mamuaba Graben (the well-exposed Beberibe Formation with thicknesses from $100 \mathrm{~m}$ up to $300 \mathrm{~m}$ ), the Rio Gramame High (a horst zone, with some basement outcrops, underlying the Beberibe Formation) and the Alhandra-Guruji-Conde-Caaporã monoclinal zone, east of the BR-101, limited to the west by a fault line. The stratigraphic sequence of the Paraiba basin represented by the Paraíba Group is complete only along the eastern monoclinal zone, where the Barreiras Group is also preserved. Along the Rio Mamuaba graben, occurrences of the Barreiras Group were not found as would be expected, and this seems to be an indication that more than one phase of vertical movement occurred, the second of which had probably removed the Barreiras Group. All these observations are preliminary and demand further geological and geophysical studies, especially at scales greater than 1/50.000.
\end{abstract}

Keywords: Pernambuco-Paraíba Basin; Cretaceous; Alhandra; Beberibe Formation; Atlantic continental margin. 


\section{PRIMEIRAS CONSIDERAÇÕES: MEIOS, MÉTODOS, OBJ ETIVOS}

A parte sul-sudeste da Bacia da Paraíba, entre Goiana e João Pessoa foi discriminada como "Sub-bacia de Alhandra” por diversos autores (Barbosa et al., 2003, sintetizando outros autores anteriores, e Souza, 2006) e deste modo fica situada entre as sub-bacias de Miriri (para norte) e de Olinda (para o sul), com base em dados geológicos gerais regionais. Várias etapas de estudos geológicos, incluindo mapeamentos sistemáticos em escalas de detalhe, têm sido realizados neste setor da margem continental atlântica, desde a década de 50, decorrente do interesse nas presenças de calcários e fosfato sedimentares, exploração de águas subterrâneas e ao treinamento (relatórios de graduação) de formandos em geologia.

O presente estudo objetivava, no início, rastrear uma possível continuidade para a zona costeira do Graben de Cariatá (Brito Neves et al., 2004; Bezerra et al., 2008), situado no Médio-Baixo Paraíba, na zona do agreste paraibano. Foi então observada a existência de um "alto estrutural” importante (Pós-Cretáceo com certa segurança, e possivelmente até Pós-Plioceno) formado pelo embasamento Pré-Cambriano (Terreno Alto Moxotó/“TAM”) e suas coberturas, o qual delimitava o Graben de Cariatá para leste. Entre estas coberturas foi observada sistematicamente uma extensa e importante unidade pedoestratigráfica, jamais mapeada e sequer e/ou mencionada em toda bibliografia preexistente, a qual foi, então, informalmente designada de Unidade Engenho Novo (Brito Neves et al., 2005), sotoposta à Formação Beberibe (clássica unidade litoestratigráfica cretácea do Pré-Maastrichtiano).

A área principal dos estudos fica entre o Rio Paraíba (ao norte) e o paralelo das cidades de També - PE e Pedras de Fogo - PB (que perlongam a divisa PE-PB, ao sul), pouco a oeste da BR-101, de francos tabuleiros, geralmente mapeados (equivocadamente) como constituídos pelo Grupo Barreiras (vide Mapa Geológico da Paraíba, CPRM, 2002, entre outros). Apenas alguns mapas esquemáticos mais antigos, como aqueles de Beurlen (1967) e o da OESA-DRN-SUDENE 1/100.000 (1976, inédito), foram mais fiéis à realidade geológica que os presentes autores defrontaram.

Ao lado dessas observações acima apostas, passou-se a verificar que a porção mais ocidental da Sub-bacia de Alhandra apresentava um comportamento regional amplo de alto estrutural (incluindo "altos" e "baixos" estruturais de segunda ordem), e mais ainda, que a cobertura do Grupo Barreiras neste domínio havia sido exumada, decorrência de sua posição neste contexto de soerguimento regional amplo e tardio. Alternativamente, o Grupo Barreiras poderia ter sido depositado apenas nas faixas mais orien- tais e mais rebaixadas, tendo como áreas fontes as porções elevadas dos depósitos cretáceos.

Tendo em vista que nas condições climáticas e do intemperismo resultante da zona da mata nordestina, a distinção de afloramentos da Formação Beberibe daqueles do Grupo Barreiras sempre foi considerada um problema de mapeamento (e, de fato continua sendo), foi efetuado um primeiro estudo de cunho sedimentológico para verificar como, através da observação dos minerais pesados, poderia ser possível obter uma ferramenta adicional para as observações dos autores e para futuros mapeamentos e perfilagens geológicos.

Neste ínterim, estava sendo realizada na área, por uma firma de consultoria (Costa Consultoria), um cadastramento detalhado dos poços tubulares para água subterrânea (cerca de 1.400 poços foram catalogados), que foi colocado à disposição dos autores. A observação minuciosa destes poços, incluindo vários que atravessavam a coluna completa da sub-bacia foram sumamente importantes para respaldar as demais observações e interpretações.

Foram realizados vários perfis de campo, longitudinais e perpendiculares à sub-bacia, tomando proveito de alguns fatos novos: a presença de vária estradas secundárias novas, resultantes dos assentamentos do INCRA em engenhos de cana desalojados (Engenho Novo é um desses casos) e dos novos cortes rodoviários por toda BR-101, consequência das obras de sua duplicação no momento. Adicionalmente, foi realizado um perfil geofísico (eletrorresistividade) expedito aproximadamente longitudinal à sub-bacia, de També - PE até a BR-230 na Paraíba (que foram acrescentadas várias outras informações geofísicas inéditas, cedidas pelo Departamento de Engenharia de Minas da UFPE, através do Prof. Edilton Feitosa).

A soma desses fatos novos da geologia constituiu respaldo e motivação suficientes para a publicação da presente comunicação. Destes fatos, os mais relevantes são a presença (agora mapeada) extensiva da Formação Beberibe na borda ocidental (acobertando a unidade pedoestratigráfica), do notável acervo de dados de subsuperfície (poços), da sedimentologia (estudo dos minerais pesados), do levantamento geofísico, da constatação de uma estruturação regional complexa ("altos" e "baixos" a serem discriminados) distinta daquela dantes divulgada (de uma ampla e simples monoclinal). Há necessidade imperiosa de revisão dos mapeamentos e dos estudos da litoestratigrafia regional, em escala de detalhe. Deve ficar claro que o esboço aqui apresentado (colocado provisoriamente e em escala 1/2.500.000) é apenas uma contribuição modesta ao problema. Estas observações preliminares servem para reiterar a advertência aos muitos que propalam e supõem (lamentavelmente) que o conhecimento geológico de nossas bacias sedimentares está completo e prescinde de investimentos e investigações adicionais. 
O propósito aqui é o de contribuição com observações concretas de campo, que deve ser somado à crítica construtiva, chamando atenção para alguns equívocos de cartografia geológica básica, em sucessivas oportunidades. Estes enganos foram inicialmente induzidos pelo fator morfologia, jogando todas as áreas planas no contexto dos tabuleiros costeiros no âmbito do Grupo Barreiras, onde muitas vezes este grupo não está presente. Em segundo lugar, os autores anteriores foram compelidos pelo fator natureza dos solos/unidades mais superficiais, posto que há as denominadas “Areias Brancas” (designação litoestratigráfica preexistente, de idade/conotação assumida como Pós-Barreiras) de várias derivações e idades, inclusive derivadas de rochas graníticas que cortam o embasamento. $\mathrm{O}$ exame pormenorizado dos afloramentos e o subsídio dos dados de poços profundos podem minorar este problema e preparar seu equacionamento para o futuro.

A análise minuciosa das principais estradas/seções que cortam a sub-bacia em epígrafe será a tônica de abordagem desta comunicação. Adicionalmente deve ser deixado claro que para o norte do Rio Paraíba (Miriri, Mamanguape etc.) e para o sul de Caaporã - PB (já para o Estado de Pernambuco), onde efetivamente não foram desenvolvidos trabalhos nesta oportunidade, foi possível (en passant) observar que problemas da mesma ordem estão ali presentes. É, portanto, preciso insistir que este tipo de revisão também é necessário para todo o contexto da Bacia Pernambuco-Paraíba.

\section{BREVE INCURSÃO À LITOESTRATIGRAFIA DA ÁREA}

\section{Embasamento cristalino}

Com referência ao substrato cristalino, desta porção mais a leste da Zona Transversal da Província Borborema, pode-se recorrer à ampla e diversificada bibliografia. O Mapa Geológico da Paraíba (CPRM, 2002) traz as informações mais que suficientes aos propósitos, e para a bacia sedimentar como um todo. Devemos destacar, na zona mais ao norte uma pequena parcela do Terreno Rio Grande do Norte (RGN, do Paleoproterozoico, ortognaisses e migmatitos), separado do Terreno Alto Pajeú (TAP, Eoneoproterozoico, ortognaisses e metagrauvacas) pelo importante Lineamento Patos. Ao sul do TAP (no paralelo de Mari) há o contato por empurrão do Terreno alto Moxotó (TAM, do Paleoproterozoico, retrabalhado, ortognaisses, migmatitos, supracrustais aluminosas de alto grau) sobre o TAP. Ao sul da sub-bacia (paralelo de Juripiranga-Ibiranga) ocorre outro lineamento importante (Coxixola-Congo) que apresenta feições complexas (terminação fasciculada que tem sido utilizado para separar o TAM (para o nor- te) da faixa neoproterozoica (supracrustais diversas, granitos de arco) do Rio Capibaribe (RC, mais para o sul). Sobre todas estas unidades pré-cambrianas, que são terrenos diversos da Província Borborema, foram encontrados remanescentes mais e menos preservados da Unidade Pedoestratigráfica Engenho Novo/“UPEN”, sempre em cotas próximas ao intervalo de 90 - $100 \mathrm{~m}$.

Particularmente este lineamento Congo-Coxixola (geralmente considerado de caráter linear e com rejeito sinistral) carece de já ser destacado, por apresentar geometria complexa, de falhas en echelon, que foram reativadas durante a evolução da sub-bacia, com importante repercussão estrutural geral, como será mencionado.

A discussão dos itens seguintes sobre o desenvolvimento litoestratigráfico da sub-bacia é facilitada pela observação e o acompanhamento dos mapas preliminares propostos (Figuras 1 e 2) e das seções geológicas transversais (Figuras 3 a 5 ) apresentadas.

\section{Unidade Pedoestratigráfica Engenho Novo/ "UPEN"}

A Unidade Pedoestratigráfica Engenho Novo foi reconhecida inicialmente e proposta informalmente por Brito Neves et al. (2005) mediante instruções do Guia Internacional (Salvador, 1994), e nos termos do Código Norte Americano (de 1983), reconhecendo as carências de seu conhecimento e as dificuldades de sua sistematização (estratigráfica, inclusive). De uma maneira geral, de sul para norte, esta unidade ocorre da zona costeira de Pernambuco (Nazaré da Mata, Aliança etc.) até, pelo menos o vale do Rio Camaratuba (ao norte), próximo à divisa da Paraíba com o Rio Grande do Norte. Para oeste da bacia foram encontrados afloramentos até o meridiano 35030', de forma descontínua. O estratotipo mais completo desta unidade edafoestratigráfica, - relacionada à formação de solos e com a evolução geomórfica regional - foi observado e proposto no alto curso do Riacho Imbé (afluente da margem direita do Rio Mumbaba), próximo da PB-910, 2 km a SSW do Assentamento Campo Verde (do INCRA). Vide Brito Neves et al. (2005), vide foto (Figura 6).

Do topo para a base foram descritos três horizontes de crosta laterítica: um horizonte superior mineralizado (tipo ferricrete), com espessura de até $3 \mathrm{~m}$ (ocorrências de quartzo, ferriargilas, ferrãs, argilas diversas etc.); um horizonte intermediário de acumulação iluvial, com alguma concentração de ferro residual, muito mosqueado, de até 2 m; e rochas do embasamento cristalino (no caso, TAM), alterado em diversos graus, com preservação da foliação metamórfica. As passagens do cristalino alterado para o não alterado variam lateralmente, dando uma disposição ondulada ao contato. Várias seções de referências (hipoestratotipos) fo- 


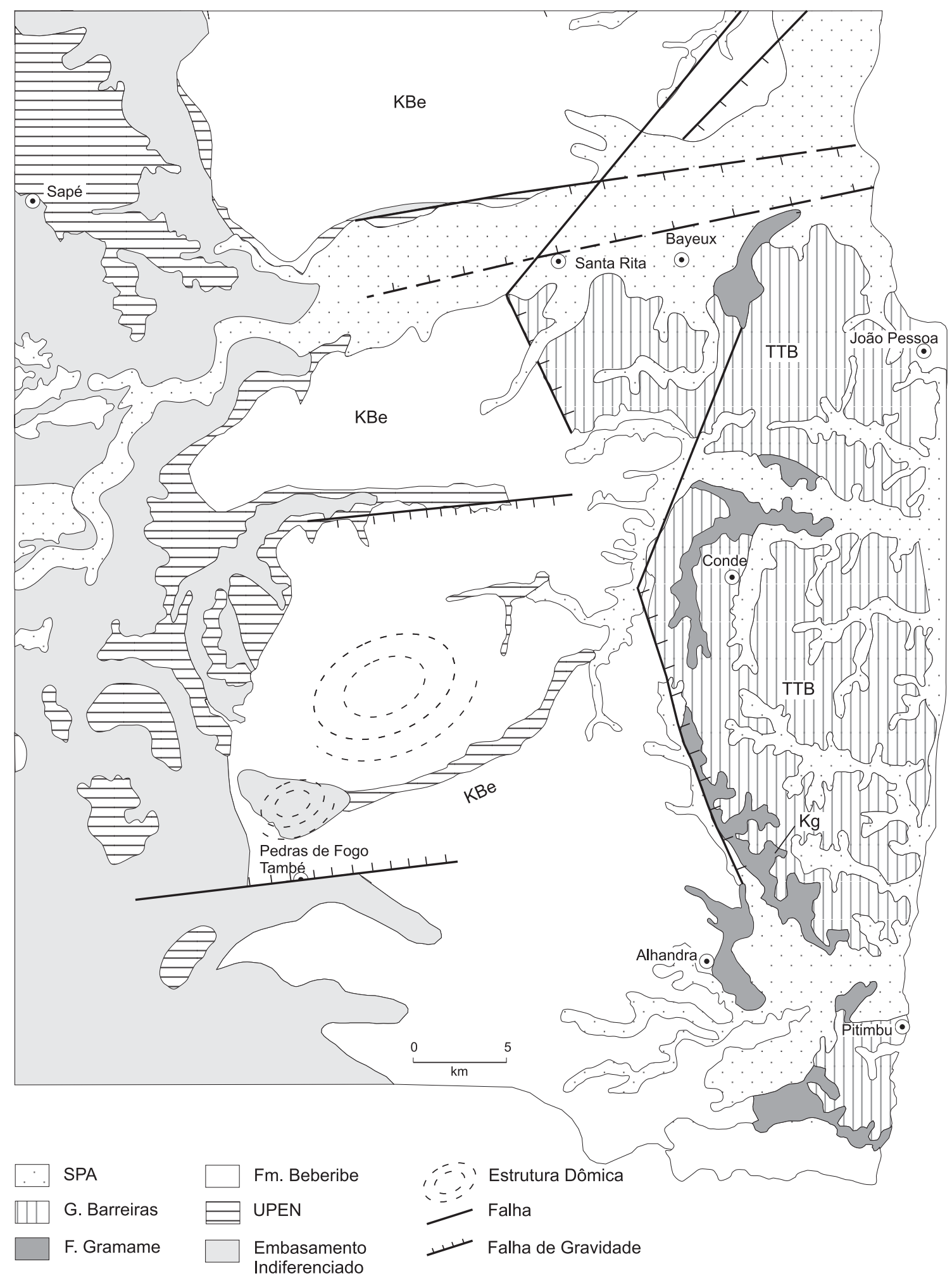

Figura 1. Mapa Geológico da porção sudeste da margem atlântica da Paraíba, do vale do Paraíba à divisa com Pernambuco. Escala original aproximada/tentativa 1/2.500.000. 


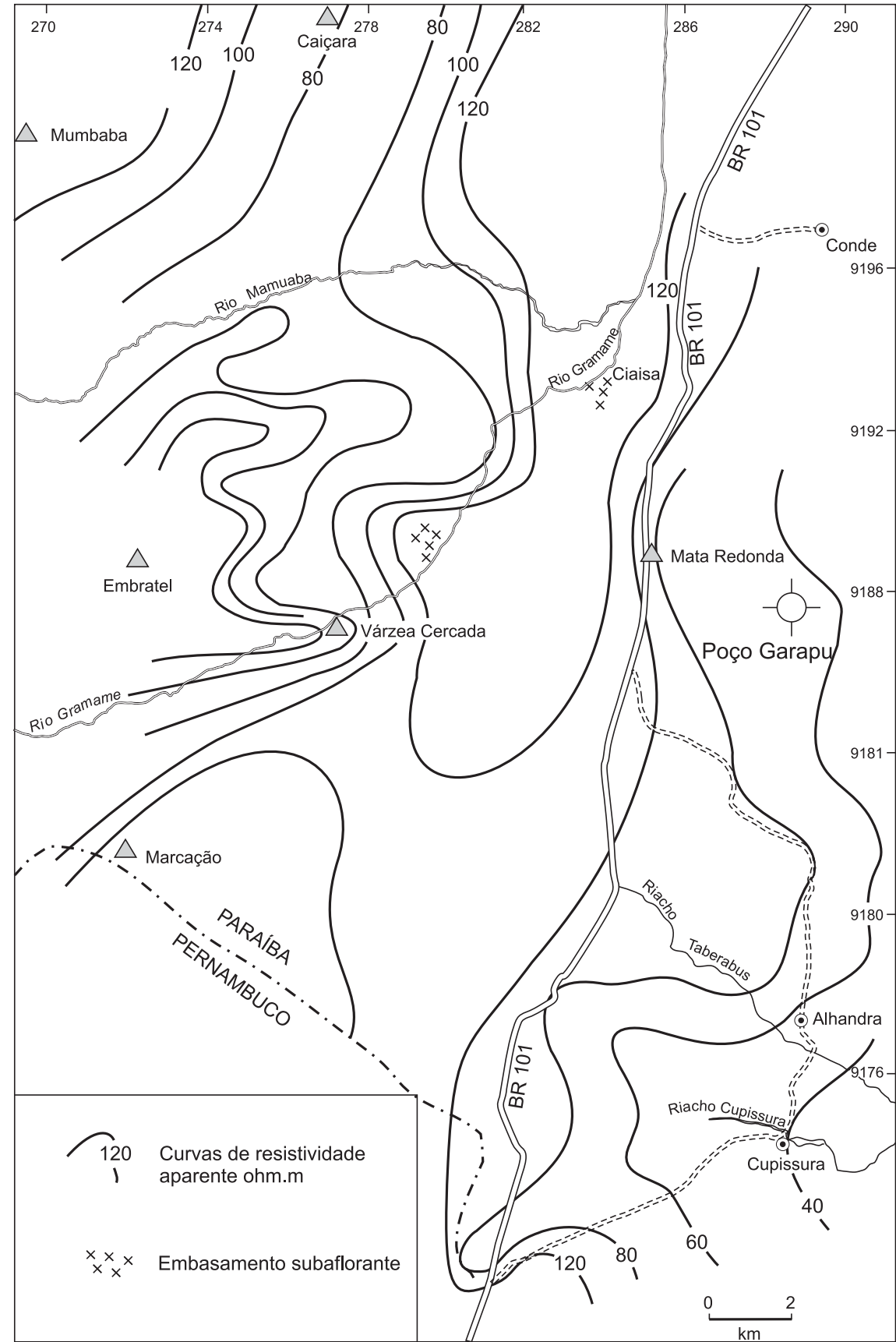

Figura 2. Mapa de eletrorresistivida de (escala de reconhecimento) da parte sedimentar mais ocidental da área. Pelo traçado das curvas, verifica-se: 1. a noroeste, curvas de 100, 120 no sentido da BR-230 (alto Rio Mumbaba). Este alto tectônico apresenta conexão para oeste com a zona de flexura, arqueada, que delimita para leste o $\mathrm{G}$ raben de Cariatá; 2. parte centro-norte (entre os rios G ramame/Mamuaba), o graben central (curvas 20, 40, 60); 3. parte central (Riacho Sal Amargo para confluência Mumbaba-Mamuaba), zona elevada, com exposições do embasamento (alguns trechos do Rio G ramame) e apresentando as mais altas resistivida des relativas: alto tectônico; 4. a parte mais oriental, balizada pela BR-101 - zona monoclinal Conde-Alhandra, onde as curvas de eletrorresistividade (de 120 para 40) apresentam traçado subparalelo. $\mathrm{Na}$ elaboração deste mapa, participou o Prof. Edilton Feitosa, da UFPE. 
Wsw

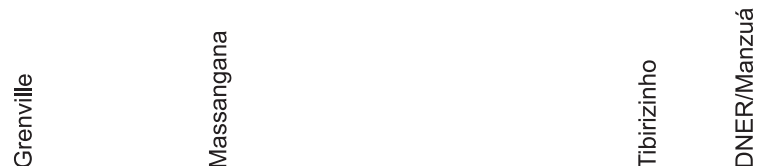

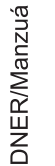

$200 \mathrm{~m}-$

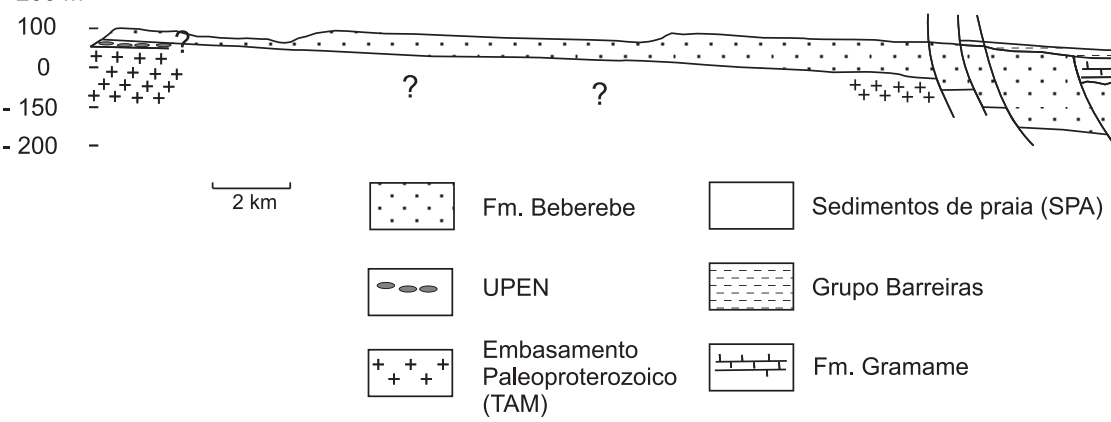

Figura 3. Seção geológica W-E na porção norte da área, do Condomínio Grenville (Rodovia BR-230 - Tabuleiro das Lagoas - Graben João Pessoa) para a Praia de Tambaú, baseada em dados de vários poços tubulares profundos.

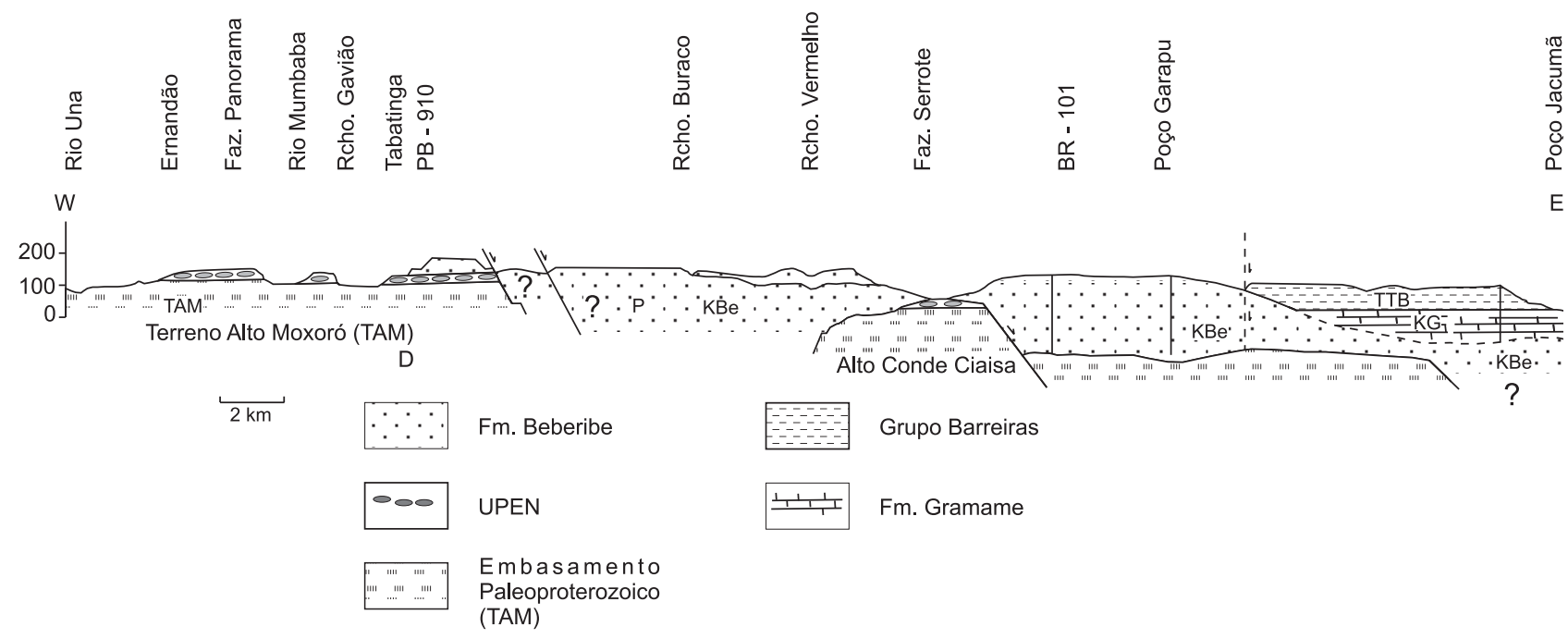

Figura 4. Seção geológica esquemática do Rio Una, afluente do Paraíba (a oeste) para a Praia de Jacumã (a leste), com base em dados de campo e de poços tubulares.

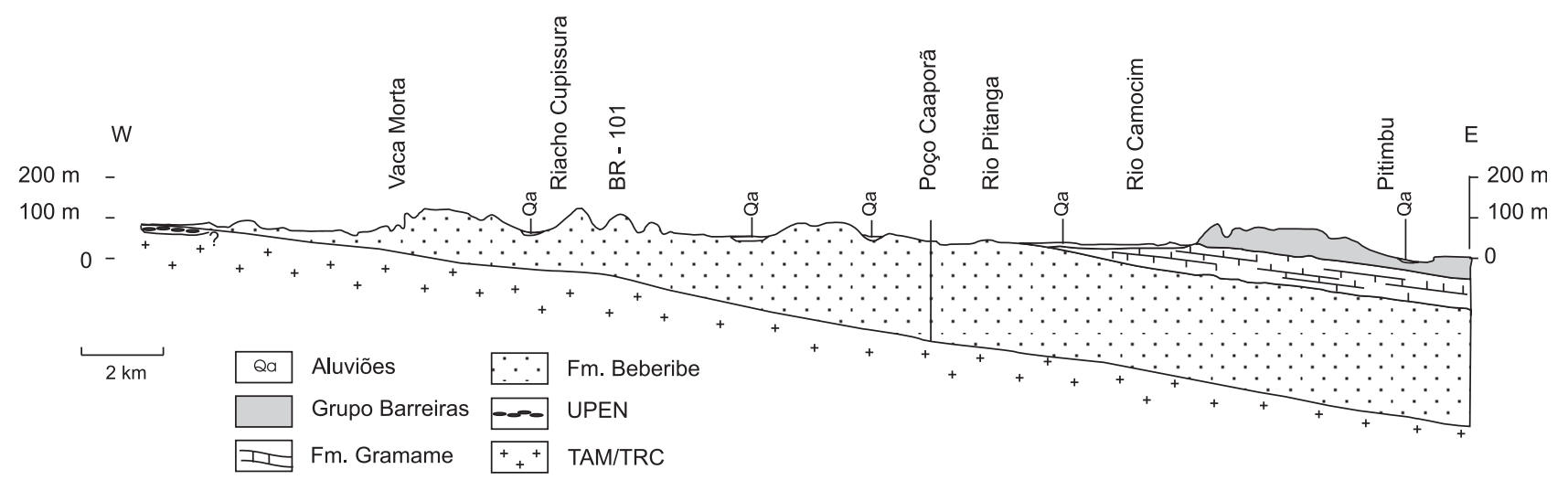

Figura 5. Seção geológica esquemática da parte mais ao sul da área, da BR-101 (Dois Rios, a oeste) para a Praia de Pitimbu, da monoclinal Conde-Caaporã, com base em dados de campo e de poços tubulares. Fonte: O ESA/SUDENE. 

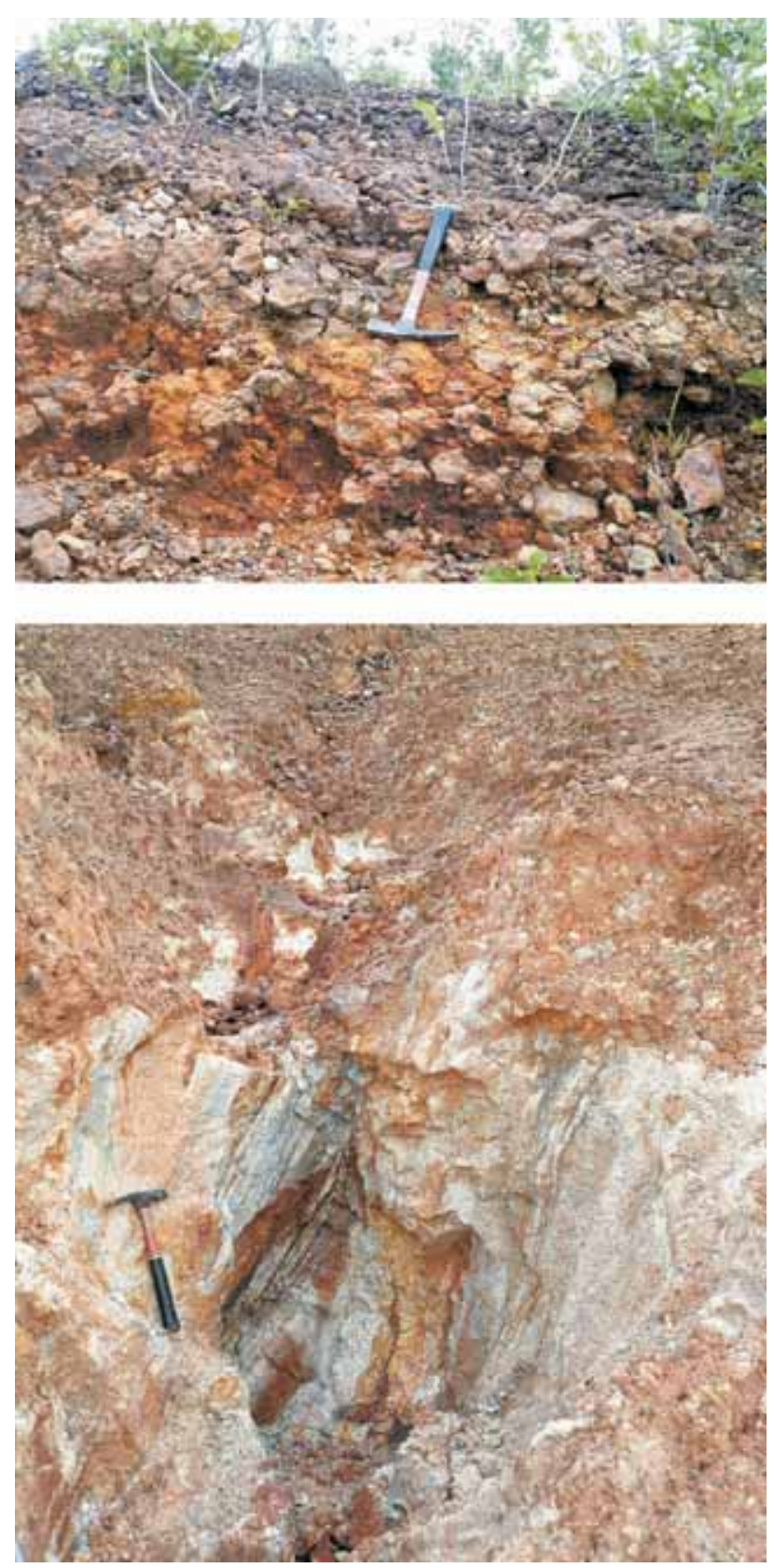

Figura 6. Foto-montagem da localidade-tipo da Unidade Pedoestratigráfica Engenho N ovo/ "UPEN". Situada no Riacho Imbé, afluente do Mumbaba, coordenadas 266000 9196000, folha de Sapé. De baixo para cima observar: o horizonte com o embasamento alterado (saprólito), com algumas estruturas preservadas; a porção central arenoargilosa, mosqueada de óxidos de ferro (sem estruturação visível); e o nível superior de concentração nodular de laterita ferruginosa. Apenas a parte mais inferior de um perfil laterítico ideal, com rochas do embasamento frescas, não aflora, está sob aluviões do riacho. ram identificadas em toda área, principalmente nas descidas para os talwegs (principalmente cotas de 90 e $100 \mathrm{~m}$ ).

Esta unidade que, caracteristicamente, encimou de forma substancial as unidades do embasamento e que hoje estão rarefeitas pela a ação do ciclo erosivo atual, apresentam histórico, características composicionais e idade ainda desconhecidas. A conexão com uma superfície de aplainamento do embasamento muito ampla, de caráter regional parece evidente (mas, a idade é problema em aberto). Em muitas ocorrências, é possível registrar de forma conspícua esta ligação com a evolução geoquímica superficial do substrato (situando-se francamente abaixo da Formação Beberibe). Mas, em algumas outras ocorrências verificam-se "passagens” e outros estilos transicionais entre esta capa edafoestratigráfica e a Formação Beberibe sobreposta. O problema da determinação da idade desta unidade é urgente.

O "UPEN" e outras ocorrências pedogenéticas da bacia costeira estão sendo objeto de amplo trabalho de estudos multidisciplinares, geocronológicos inclusive, com apoio da FAPESP (sob comando da Dra. Dilce Rossetti, do INPE), devendo-se aguardar os resultados destes estudos dirigidos.

\section{Sub-bacia de Alhandra}

De um modo geral, a litoestratigrafia da Bacia Pernambuco-Paraíba tem sido exaustivamente estudada, em trabalhos de diversas décadas (vide o notável pioneiro de Beurlen, na sua retrospectiva de 1967), com sínteses publicadas por Barbosa et al. (2003), Lima Filho et al. (2006), Barbosa e Lima Filho (2006) e, mais recentemente, por Córdoba et al. (2007, com apoio da ANP e Petrobras), de forma que podemos ser bastante concisos neste aspecto. Há alguns poucos e novos pontos a acrescentar.

No tocante ao comportamento estrutural do contexto, deve ser reiterado que ele foi deixado praticamente à margem nos trabalhos anteriores, sob um estigma de uma estruturação monoclinal simples e ampla, o que não é fato, que não encontra respaldo nas muitas observações de campo (e de dados de subsuperfície), de forma que várias observações adicionais precisam ser feitas.

Com estas e como subproduto destas observações, deve ser reafirmado que houve alguns equívocos (involuntários) nos mapeamento geológicos preexistentes. Muitas das áreas consignadas como do Grupo Barreiras (fundamentados mais em morfologia de aerofotos que em trabalhos de campo), na verdade são, ora sendo áreas de exposição da “UPEN”, ora áreas de exposição da Formação Beberibe.

No momento, poucas modificações podem ser apostas às colunas da sub-bacia até hoje publicadas, consoante o fecho proposto por Córdoba et al. (2007), baseados em um conhecimento que transcende a sub-bacia em apreço. Insistimos 
na inserção/discussão da "UPEN”, vinculada com o topo do embasamento dos terrenos RC, TAM e TAP (pelo menos) e com a parte basal da Formação Beberibe, que é uma unidade francamente mapeável em escalas superiores a 1/100.000. Além disso, seu significado em nível regional é importante, ainda que seus processos de gênese e de idade sejam ainda não conhecidos, e que são objetos de amplo programa de pesquisas paralelo, já comentado anteriormente.

No caso do Grupo Barreiras, mesmo restringindo em muito sua área de exposição, o cotejo entre estas áreas e outras de outros segmentos da província costeira sul-americana motiva os autores a opção, no momento, pela designação hierárquica de grupo. Isto, na esperança e muito confiantes que este vai ser discriminado em formações para o futuro.

No tocante à Formação Beberibe, foram encontrados, na maioria de suas exposições arenitos brancos a muito brancos, médios a grossos, com grânulos mal selecionados, e com estratificação plano-paralela (predominante) pobremente desenvolvida, bancos de 0,5 até $2 \mathrm{~m}$, sem grandes variações de fácies. A parte basal da unidade aflora esparsamente (Rio Sal Amargo, Rio Papocas, Rio Dois Rios, Mumbada do Penicho etc.) e está representado por um conglomerado monomícto a oligomítico (clastos muito bem rolados de quartzo, quartzito, gnaisses) de até $15 \mathrm{~cm}$, suportados por matriz, esta de natureza arenítico-arcoseana, na maioria das vezes. Há alguns casos interessantes (como em Dois Rios, na BR-101) onde estes paraconglomerados se alternam com bancos de até $0,30 \mathrm{~m}$ de argilas muito brancas (que no caso é igual à matriz dos conglomerados). Este conglomerado pode ser observado diretamente sobre o embasamento em vários pontos da margem sul do Rio Paraíba, inclusive na BR-230 (quilômetro 62 da BR-230), assim como foi observado e palmilhado por todo o contato com o embasamento, ao longo do entorno do "Horste" Tabuleiro das Lagoas, a ser comentado. O caráter de leques fluviais para este conglomerado basal parece apropriado. Para o conjunto restante de arenitos sobrepostos, detectados no campo e em centenas de poços tubulares (espessura máxima observada de $270 \mathrm{~m}$ ), a interpretação de depósito fluvial persiste, provavelmente fácies de canais entrelaçados (braided) de alta energia, com intercalações locais de arenitos finos de planície aluvial (Barbosa et al., 2004). Para o topo, os arenitos gradam para termos calcíticos e para calcarenitos flúvio-deltaicos e flúvio-lagunares, localmente (no Estado de Pernambuco) separados como “Formação Itamaracá”. Estes termos superiores só foram detectados em poços tubulares na área em consideração. Quanto às espessuras da Formação Beberibe, as maiores possanças estão no contexto do graben-depressão da Grande João Pessoa (incluindo parte oriental de Santa Rita, a cidade de Bayeux), com valores máximos obser- vados nos poços de Buraquinho (303 m), do Alto Mateus (279 - 274 m), Termas (256 m), na grande João Pessoa.

Várias observações mineralógicas sobre os minerais pesados do Grupo Barreiras e da Formação Beberibe serão apostos em um dos itens seguintes, procurando contribuir por ferramentas auxiliares que sirvam para melhor discriminação entre ambas, em alguns locais.

A idade Pré-Maastrichtiana (Pré-Formação Gramame) da Formação Beberibe é inconteste. A posição do Coniaciano ao Campaniano é viável, baseada em inferências diretas paleontológicas e faciológicas. No trabalho de Lima Filho et al. (2006), a Formação Beberibe é colocada no Coniaciano-Santoniano, com a porção mais carbonática (Itamaracá) ocupando o Campaniano e início do Maastrichtiano, e a Formação Gramame é colocada no Maastrichtiano Superior.

Para Córdoba et al. (2007), na carta estratigráfica proposta para a evolução desta porção da margem continental, o contexto de Beberibe-Itamaracá e Gramame é classificado como "Sequência Drifte Transgressiva Superior”, de idade Neoturoniana-Neomaastrichtiana (Sequência K88K130). Esta sequência é separada por uma discordância (Maastrichtiana/Daniana) da "Sequência Drifte Regressiva”, que ocorre, sobretudo, em Pernambuco. Nesta "Sequência Drift Regressiva”, os autores discriminaram uma parte "Inferior" (do Paleoceno Inferior ao Mioceno Inferior, Sequência E10-N10) e uma parte "Superior" (do Mioceno Médio ao Plioceno, Sequência N20-N50). Nesta última estariam incluídas parte da Formação Maria Farinha e o Grupo Barreiras.

A Formação Gramame corresponde ao máximo da transgressão do Grupo Paraíba na sub-bacia em apreço, sendo constituída de rochas carbonáticas claras, calcários argilosos, alguns arenitos calcários, com um horizonte fosfático basal, objeto e alvo de muitos trabalhos específicos. A Formação Gramame aflora muito pouco na sub-bacia sob consideração, em condições topográficas e estruturais favoráveis da estruturação monoclinal situada a leste da BR-101, a ser discutida, em cotas topográficas muito baixas, em geral (abaixo da cota de $30 \mathrm{~m}$ ). Em alguns casos ela funciona como horizonte guia, para a separação da Formação Beberibe (abaixo) para com o Grupo Barreiras (situado na capa). Esta é a melhor situação para o geólogo, quando a Formação Gramame pode ser de pronto identificada.

Dados de dezenas de poços mostram espessuras médias predominantes entre 40 - $50 \mathrm{~m}$, havendo um trecho, a oeste de João Pessoa (municípios de Bayeux e Santa Rita) no qual vários poços profundos não detectaram a presença da Formação Gramame, o que pode indicar erosão e tectonismo Pré-Barreiras, mas isto demandaria a perfilagem geofísica nestes poços. Isto está indicado na seção geológica (Figura 3) apresentada. 
Excepcionalmente, há poços com espessuras acima de 60 m (vide Cadastro da Costa Consultoria no contexto da grande João Pessoa). No poço mais completo amostrado (Buraquinho), a espessura atravessada foi de 56 m. Há algumas outras indicações excepcionais acima de $80 \mathrm{~m}$ e até de 100 m (Poço de Jacumã), mas as amostras de calha precisariam ser revistas. É possivel, no caso de Jacumã e adjacências, que estes poços tubulares estejam atingindo a Formação Gramame e a unidade regressiva sobrejacente (Formação Maria Farinha), que chega a aflorar sotoposta ao Grupo Barreiras apenas em alguns pontos (ao longo da beiramar, vide foto, Figura 12). As fácies calcárias da Formação Gramame são sempre muito homogêneas, creme a cinza, com calcários margosos com finos filmes de argila.

A Formação Maria Farinha (parte da ampla "Sequência Drifte Regressiva” de Córdoba et al., 2007) é constituída de calcários clásticos, finos a grossos e margas calcárias do ciclo de regressão (com interessante conteúdo faunístico e é riquíssima em ichnofósseis), aflora muito pouco em toda sub-bacia, mais precisamente, ao sul da Praia de Jacumã (Praias de Tabatinga e adjacências, vide foto, Figura 12), ficando de fora da escala do mapa geológico apresentado (Figura 1).

Com relação ao "problema” da distinção em campo da Formação Beberibe para o Grupo Barreiras (Alheiros et al., 1988; Lima Filho e Melo, 2007), na falta de horizonte-guia ou de outras informações decisivas, o que será tema do item seguinte, é necessário assinalar as observações primorosas de Beurlen (1967) na primeira síntese sobre a Bacia Pernambuco-Paraíba. Estas observações, e a cartografia apresentada por aquele autor, serão aqui assinaladas por dois motivos fundamentais: primeiro, elas são observações verdadeiras, frutos de trabalhos de campo; segundo, porque elas não foram lidas nem consideradas de forma suficiente pela maioria absoluta daqueles que mapearam a bacia costeira. Beurlen (1967, p. 46) afirmou sobre a Formação Beberibe:

“... Esta formação arenítica aflora em grande extensão: da região de Abreu e Lima (município de Paulista) até a região do vale do Rio Gramame, quase todos os extensos planaltos sobre os quais vai a estrada central (BR-101) Recife-João Pessoa e ao oeste desta central, representam verdadeiras chapadas desta formação, nas quais o arenito aflora diretamente, superficialmente intemperizado, ou coberto com uma fina capa de areias brancas. A superfície intemperizada pode simular o aspecto de Barreiras, que aliás falta completamente na superfície das chapadas e ocorre apenas na encosta dos vales que cortam as chapadas. Preferimos por isto chamar estes planaltos de 'chapadas', em vez de 'tabuleiros', porque o termo 'tabuleiro', de acordo com o costume da Petrobras é usado para planaltos constituídos pelos depósitos do Barreiras... Estes tabuleiros ocorrem somente ao leste da estrada central ao longo da própria costa...”.

\section{CONTRIBUIÇÃO DA SEDIMENTOLOGIA: DISTINÇÃO LABORATORIAL DAS FORMAÇÕES BEBERIBE E GUARARAPES (GRUPO BARREIRAS)}

\section{Aspectos gerais}

Nesta parte do trabalho procurou-se levantar uma amostragem da população de minerais pesados contida nos sedimentos das formações Beberibe e Guararapes (Grupo Barreiras), visando obter elementos para a melhor diferenciação entre ambas. Ou seja, a busca de mais uma ferramenta, como tentativa nova de encontrar subsídios adicionais, dando continuidade ao trabalho original de Coutinho e Coimbra (1973). A tentativa é de contribuir (tentar ajudar na distinção) na polêmica gerada pelos mapeamentos regionais, onde esta distinção nem sempre ficou correta. Alguns dados interessantes para discriminação parecem ter sido obtidos e devem ser devidamente mais explorados para o futuro.

Como já mencionado, as condições de intemperismo (quente-úmido) reinantes na faixa costeira, a predominância de tabuleiros (vide a transposição das observações de Beurlen, 1967, acima), assim como a extensa plantação de canaviais (ao que se soma a colocação de adubos, defensivos agrícolas, poluição da exploração agroindustrial etc.) por muitas vezes não permitem em “afloramentos” (de má qualidade nos cortes de estrada, muito sujos) a distinção taxativa entre o Grupo Barreiras e a Formação Beberibe (e mesmo entre outros sedimentos por ventura ali ocorrendo). Isto tem levado várias gerações de geólogos a erros sistemáticos/inadvertidos de mapeamento, na falta de poços profundos devidamente perfilados (separação/discriminação das unidades também dificultada em amostras de calha) e outros guias/dados adicionais. As Tabelas 1 e 2 a seguir apresentadas, mostram esta participação de minerais pesados.

\section{Discussão dos dados}

A análise dos resultados expressos nas Tabelas 1 e 2 mostrou os valores médios de índices ZTR seguintes que poderão alicerçar futuras discriminações, conforme ressaltado abaixo de cada tabela.

a. Os sedimentos $\mathrm{AB}$ (Beberibe) apresentaram valores médios de 93,2, sendo que em 90\% dos casos estes valores estão acima de 90. 
b. Os sedimentos coletados no Grupo Barreiras (FG) apresentam valores de média 80,9, sendo que em 100\% dos casos estes valores estão abaixo de 88. Outros elementos de diferenciação podem ser auferidos da leitura detalhada das tabelas.

Deste grupo de amostras FG, foi excluído o cálculo da amostra FG - 3 que apresentou proporção normalmente grande dos minerais improváveis em sedimentos (mica, fibrolita). Foi coletada na fábrica de cimento CIPASA e parece provir de regolito de micaxisto ou de sedimento contíguo à rocha fonte xistosa.

As amostras foram coletadas após várias viagens de campo em busca de localidades típicas indiscutíveis (em termos de estruturas primárias e litologias), nas folhas 1/100.000 de João Pessoa e Sapé. Futuras correções do trabalho e mesmo das formações aqui consideradas representantes seguras podem vir a ocorrer. Críticas construtivas e trabalhos adicionais neste campo de abordagem serão sempre bem-vindos e necessários. Em parte, estes estudos estão em processo (Profa. Dilce Rosseti et al., em andamento, conforme já mencionado anteriormente) com maior aprofundamento no tema.

Os afloramentos amostrados constituem-se normalmente de cortes de rodovias (raros são suficientemente limpos), alguns poucos em paredões de pedreiras e nas falésias típicas do Grupo Barreiras (na “quebra” dos tabuleiros antes do domínio da planície costeira), em processo de destruição pelo ciclo erosivo atual. Ocorrências típicas da chamada Formação Guararapes (FG) do Grupo Barreiras podem ser reconhecidas por suas características megascópicas: má seleção, estratificação irregular e tendência a se intemperizar em manchas de cores variegadas. Adicional a isto, foram utilizados alguns mapas locais de detalhe, que merecem crédito.

Normalmente, os sedimentos da Formação Beberibe (AB), costumam apresentar melhor seleção, maior proporção de quartzo clástico ou recristalizado, bem como cores homogêneas claras. A maior parte dos afloramentos visitada teve respaldo de mapas geológicos prévios, de pesquisas anteriores e/ou do controle por poços tubulares próximos.

Certo número de ocorrências (afloramentos muito sujos, exposição comprometida por vários fatores) exibe aparência não decisiva para qualquer das duas formações. São, portanto, mega e microscopicamente incógnitas, ainda, necessitando para seu reconhecimento, da utilização de procedimentos laboratoriais adicionais. Estas amostras ditas de "incógnitas” estão sendo gradativamente analisadas, à luz dos dados obtidos nas amostras típicas (índice ZTR, por exemplo) e outros procedimentos laboratoriais.

Tabela 1. Minerais pesados da Formação Beberibe (AB, indiferenciado). Média final = 93,2. Cerca de 90\% dos casos, valores de ZTR (índice obtido pela soma de grãos de zircão, turmalina e rutilo) acima de 90 . Abreviações: $\mathrm{F}=\%$ de grãos da fração fina: 0,066 - 0,125 mm; G = \% de grãos da fração grossa: 0,125 - 0,250 mm; pr = valores inferiores a $1 \%$.

\begin{tabular}{|c|c|c|c|c|c|c|c|c|c|c|c|c|c|c|c|c|}
\hline & \multicolumn{2}{|c|}{$A B-1$} & \multicolumn{2}{|c|}{$A B-2$} & \multicolumn{2}{|c|}{$A B-3$} & \multicolumn{2}{|c|}{$A B-4$} & \multicolumn{2}{|c|}{$A B-5$} & \multicolumn{2}{|c|}{$A B-6$} & \multicolumn{2}{|c|}{$A B-7$} & \multicolumn{2}{|c|}{$A B-8$} \\
\hline & \multicolumn{2}{|c|}{9186096} & \multicolumn{2}{|c|}{9194590} & \multicolumn{2}{|c|}{918650} & \multicolumn{2}{|c|}{9194698} & \multicolumn{2}{|c|}{9182364} & \multicolumn{2}{|c|}{9143892} & \multicolumn{2}{|c|}{9197852} & \multicolumn{2}{|c|}{9199344} \\
\hline & \multicolumn{2}{|c|}{276705} & \multicolumn{2}{|c|}{274443} & \multicolumn{2}{|c|}{268050} & \multicolumn{2}{|c|}{267800} & \multicolumn{2}{|c|}{269816} & \multicolumn{2}{|c|}{265053} & \multicolumn{2}{|c|}{265574} & \multicolumn{2}{|c|}{268317} \\
\hline & \multicolumn{2}{|c|}{$\begin{array}{l}\text { Eng. } \\
\text { Giasa }\end{array}$} & \multicolumn{2}{|c|}{ Mamuaba } & \multicolumn{2}{|c|}{$\begin{array}{c}\text { Fz. } \\
\text { Jangada }\end{array}$} & \multicolumn{2}{|c|}{$\begin{array}{c}\text { Alto } \\
\text { Mamuaba }\end{array}$} & \multicolumn{2}{|c|}{$\begin{array}{c}\text { Rio } \\
\text { Utinga }\end{array}$} & \multicolumn{2}{|c|}{$\begin{array}{c}\text { Fz. } \\
\text { Jacinto }\end{array}$} & \multicolumn{2}{|c|}{$\begin{array}{c}\text { Fz. } \\
\text { Corvoada }\end{array}$} & \multicolumn{2}{|c|}{$\begin{array}{c}\text { Pedr. } \\
\text { Evenildo }\end{array}$} \\
\hline & $\mathbf{F}$ & G & $F$ & G & $\mathbf{F}$ & G & $F$ & G & $F$ & G & $F$ & G & $F$ & $\mathbf{G}$ & $F$ & G \\
\hline Andaluzita & - & - & $\mathrm{pr}$ & $\mathrm{pr}$ & $\mathrm{pr}$ & 1 & 1 & 2 & - & 2 & 1 & 1 & $\mathrm{pr}$ & $\mathrm{pr}$ & - & - \\
\hline Cianita & 3 & 7 & 2 & 7 & 5 & 8 & 2 & 6 & 2 & 6 & 2 & 5 & 3 & 5 & 3 & 8 \\
\hline Estaurolita & $\operatorname{Pr}$ & 2 & 1 & $\mathrm{pr}$ & $\mathrm{pr}$ & $\mathrm{pr}$ & 1 & 3 & $\mathrm{pr}$ & 1 & 1 & 2 & - & 1 & - & $\mathrm{pr}$ \\
\hline Mica & - & $(2)$ & - & - & - & - & - & - & - & $(4)$ & - & - & - & - & - & (1) \\
\hline Rutilo & 1 & 1 & 3 & 2 & 2 & 2 & 1 & 4 & 4 & 5 & 5 & 1 & 2 & 3 & 3 & 4 \\
\hline Turmalina & 4 & 34 & 12 & 30 & 7 & 32 & 8 & 23 & 11 & 25 & 11 & 25 & 10 & 20 & 16 & 56 \\
\hline Zircão & 92 & 54 & 82 & 60 & 86 & 57 & 87 & 62 & 83 & 61 & 82 & 71 & 89 & 59 & 76 & 32 \\
\hline & - & 2 & & & & & - & $\mathrm{pr}$ & & & $\mathrm{pr}$ & $\mathrm{pr}$ & $\mathrm{pr}$ & $\mathrm{pr}$ & - & $\mathrm{pr}$ \\
\hline Outros & & zio, & - & - & - & - & $\tilde{n}$ id & ntif. & - & - & $\begin{array}{l}\text { top } \\
\tilde{n} \text { id }\end{array}$ & & $\begin{array}{l}\text { ep } \\
\text { gra }\end{array}$ & & sillir & anita \\
\hline n.t.c. & 674 & 225 & 630 & 124 & 664 & 173 & 366 & 155 & 651 & 250 & 747 & 241 & 330 & 97 & 100 & 123 \\
\hline 7TR & 96 & 82 & 97 & 92 & 95 & 91 & 96 & 89 & 98 & 88 & 98 & 92 & 96 & 94 & 95 & 92 \\
\hline $21 \pi$ & & & $M=$ & 4,5 & & & $M=$ & 2,5 & & & & & & & $M$ & 93,5 \\
\hline
\end{tabular}




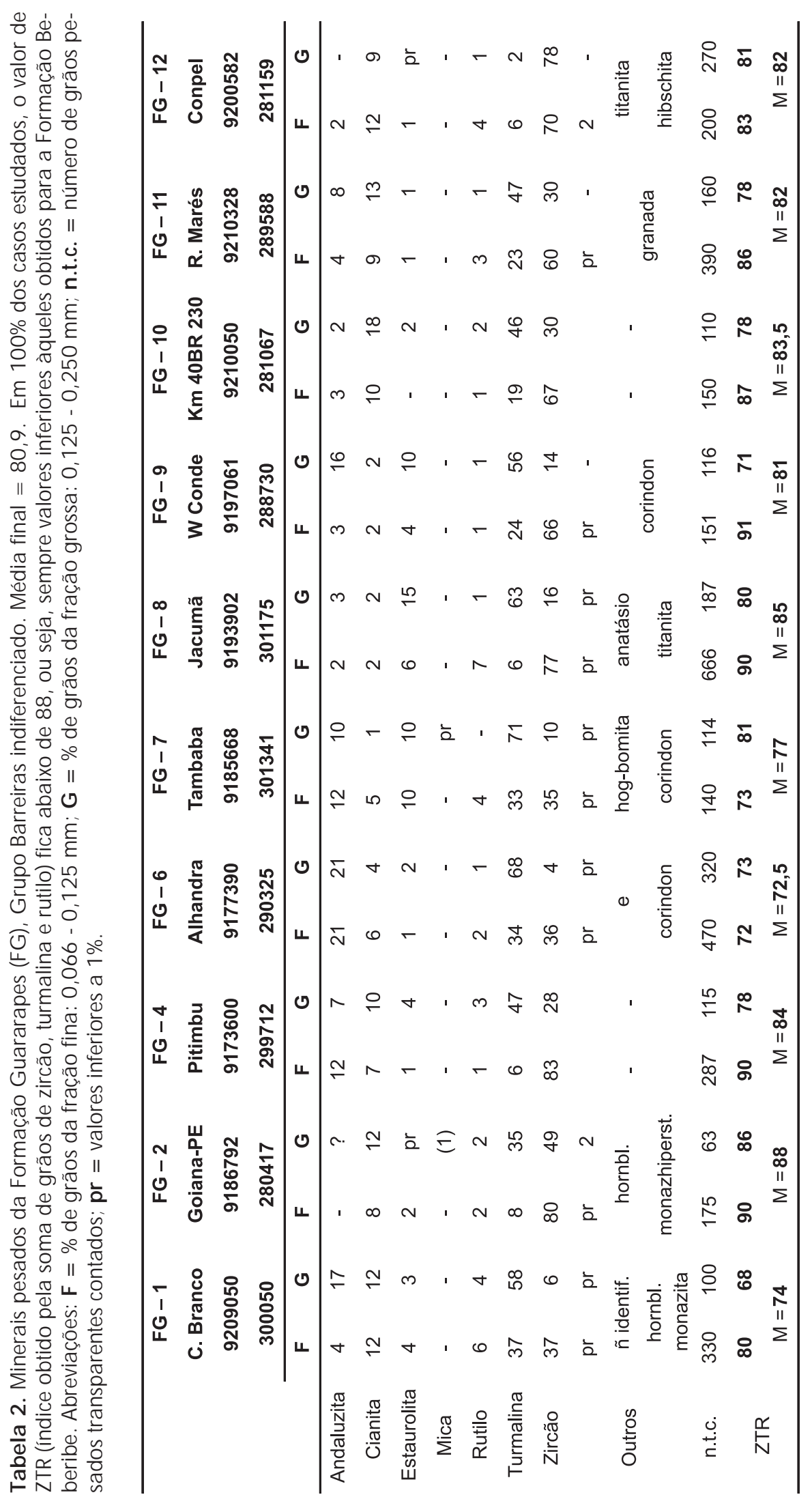


Como base para distinção daquelas formações, foi escolhida neste trabalho a representação de ZTR, ou seja, a porcentagem de zircão, turmalina e rutilo, presentes na fração de minerais pesados transparentes.

As amostras foram coletadas em pontos irregularmente espaçados, listadas nas Tabelas 1 e 2, e principalmente nas folhas Sapé e João Pessoa. No campo, foram recolhidas porções em um ou dois níveis vizinhos, compondo uma amostra de 1 a $2 \mathrm{~kg}$. No laboratório seguiu-se a seguinte marcha: amostras quarteadas de 200 a 300 g foram lavadas por sifonamento, secadas em estufa a $60^{\circ} \mathrm{C}$ e peneiradas com separação final de frações entre 66 e 125 micra e 125 e 250 micra. As frações acima e abaixo destes limites foram rejeitadas por apresentarem minerais pesados em pequeno número e de difícil estudo óptico. A separação das frações leves e pesadas foi efetuada em funis apropriados utilizando-se bromofórmio de $d=2,89$. A seguir, foram montadas lâminas com as frações pesadas das duas granulações, fina e grossa. Tendo em vista a baixa concentração de pesados transparentes, os mais numerosos pesados opacos foram eliminados com imã ou simplesmente não contabilizados e assim, não representados nas tabelas.

O estudo microscópico foi executado em montagens não permanentes, isto é, com os grãos imersos em líquidos de índice de refração $n$ entre 1,62 e 1,65. Em meios de tais índices, minerais como andaluzita perdem quase totalmente o relevo entre polarizadores descruzados, destacando-se nitidamente de outros minerais transparentes. Os resultados das contagens obtidas são apresentados nas tabelas. Aí também se encontram, entre parênteses, valores para micas não computados na soma dos minerais restantes da coluna. Valores inferiores a 1\% estão designados como pr. Sob as colunas registram-se adicionalmente o número de pesados transparentes não micáceos contados (n.t.c.) e a relação porcentual dos ultraestáveis ( ZTR).

Os minerais pesados transparentes identificados tanto na Formação Beberibe quanto na Guararapes fazem parte, sem dúvida, de fontes oriundas de associações de médio grau metamórfico. Neste caso, andaluzita, cianita e estaurolita são relativamente comuns, sempre acompanhadas dos ultraestáveis zircão, turmalina e rutilo.

É necessário acrescentar aqui, a reboque deste estudo, que alguns outros minerais encontrados em sedimentos Barreiras da costa oriental brasileira (vide Coutinho e Coimbra, 1973), são raros ou inexistentes na Paraíba. Tais são os casos de anatásio, cloritoide, coríndon, espinélio, granada, hornblenda, sillimanita e titanita, o que é atribuído como resultado de fontes distintas dessas da Paraíba.

Reitera-se aqui a análise dos resultados expressos nas Tabelas 1 e 2 que mostrou os valores médios de índices ZTR seguintes que poderão alicerçar futuras discriminações, conforme ressaltado abaixo de cada uma das tabe- las. Os sedimentos AB (Beberibe) apresentaram valores médios de 93,2, sendo que em $90 \%$ dos casos estes valores estão acima de 90 . Os sedimentos coletados no Grupo Barreiras (FG) apresentam valores de média 80,9, sendo que em $100 \%$ dos casos estes valores estão abaixo de 88 . Outros elementos de diferenciação podem ser auferidos da leitura detalhada das tabelas.

Estes dados acima são considerados ferramentas potenciais e adicionais importantes para a distinção das formações Beberibe e Guararapes (do Grupo Barreiras) em afloramentos problemáticos, mas são necessárias mais investigações. Foram feitos alguns testes e a utilização do índice ZTR (para distinguir uma unidade da outra em afloramentos considerados problemáticos), e esta ferramenta se mostrou eficiente e promissora, mas certamente não pode ser considerada única e exclusiva. Alguns problemas foram encontrados nos níveis mais inferiores da Formação Beberibe (arenitos conglomeráticos e conglomerados), onde os valores de ZTR caíram bastante, se aproximando daqueles valores obtidos no Grupo Barreiras.

\section{FEIÇÕES LITOESTRUTURAIS E DE CARTOGRAFIA GEOLÓGICA}

\section{Quatro rodovias norte-sul subparalelas, quatro seções e quatro cartografias distintas, a considerar}

Esta porção estudada (Figuras 1 e 2) da Sub-bacia de Alhandra é cortada na direção norte-sul (nas folhas Sapé e João Pessoa) por quatro estradas mais ou menos paralelas - no mesmo panorama fisiográfico geral de "tabuleiros” (e/ou nesta indevidamente incluídas), mas que encerram diferenças significativas nos seus contextos, tanto nos quadros litoestratigráficos em exposição como nas tramas litoestruturais e significado tectônico, como pode ser visto na Figura 1. Além de um quadro subsidiário de muitas vias de acesso mais recentes (ligações entre as agrovilas do INCRA de muitas fazendas de cana-de-açúcar desapropriadas), a presença de algumas novas rodovias estaduais e, como já mencionado, a duplicação (em franco processo) da BR-101, federal, com muitos cortes novíssimos, todos foram fatores que ajudaram muito o estudo geológico e geofísico

Da porção mais ocidental e norte-ocidental (início do agreste) para a faixa litorânea, a leste, devem ser destacados:

a. PB-082 (saída sul da BR-230 para Itabaiana) e sua ligação para Pedras de Fogo, via distrito de Una

Esta é uma rota de exposição da seção do embasamento raso (ortognaisses do TAM), constituindo a borda arqueada que serve de margem mais ocidental da sub-bacia, 
e que interrompe a estruturação (continuidade para lestenordeste) do Graben Cariatá. (Bezerra et al., 2008).

Esta zona arqueada de direção NNW-SSE (a ser aqui discriminada como També-São Miguel de Taipú) foi a primeira estrutura regional a ser identificada, pois ela funciona como uma espécie de "linha divisória aparente” entre o Graben Cariatá, de direção geral WSW-ENE (vide Brito Neves et al., 2004, Bezerra et al., 2008) e a sub-bacia em epígrafe.

Este domínio cartográfico é revestido quase continuamente pela Unidade Pedoestratigráfica Engenho Novo ou "UPEN". Trata-se de uma linha francamente caracterizada por tabuleiros (cotas de 120 - $140 \mathrm{~m}$ ) e com algumas areais aí presentes, fruto de processos regionais de geoquímica de superfície, desenvolvido no embasamento (TAM) e em granitos (tipo "Bela Rosa”) nele intrusivos (onde aparecem "areias brancas" como expressão litológica mais superficial). "UPEN” se expõe extensivamente neste setor, assim como suporta a feição da linha festonada de cuestas que consigna o limite ocidental da sub-bacia. Quase que invariavelmente, o "contato" entre as rochas (com estruturas preservadas) do embasamento e o início da "UPEN" está em cotas pouco acima de $90 \mathrm{~m}$. Por todas as vezes que a estrada cruza algum talweg, o embasamento aflora francamente (pouco alterado ou fresco).

\section{b. PB-030 - ligação da BR-230 (Km 54) para Pedras} de Fogo-PB e També-PE

Esta é a linha que perlonga a fração mais ocidental da Sub-bacia de Alhandra, apresentando afloramentos praticamente contínuos da Formação Beberibe - em paralelismo com o seu contato basal com a "UPEN", que fica entre 0,2 e 2,0 km mais para oeste (na seção/setor descrito acima, no item “a”).

A Formação Beberibe ocorre francamente, em diversas escarpas, vertentes, vales, mesmo nos cortes e até empréstimos da rodovia PB-030. Ainda participa de algumas escarpas que formam a borda ocidental da sub-bacia, sobreposto à “UPEN”. A Formação Beberibe é composta de arenitos médios e conglomeráticos, muito claros (com desenvolvimento expressivo de areias brancas na superfície). Este panorama estratigráfico, onde a Formação Beberibe está francamente sobrejacente à "UPEN" pode ser observado em todas as vertentes de alto curso dos rios Mumbaba, Una e Paraibinha, rios que deste contato recebem muita contribuição hídrica (das fontes de contato e de depressão).

A sucessão estratigráfica (em parte) seguinte, de baixo para cima: TAM + granitos/“UPEN”/Beberibe (muitas vezes com expressiva cobertura de areais de seu intemperismo) é notória. Nestes casos as cotas topográficas regionais (dos “tabuleiros”) se elevam bastante, atingindo valores acima de 170 m (circunstancialmente, em áreas dômicas, atingem elevações maiores).
Infelizmente, na maioria dos mapas geológicos publicados esta "sucessão litoestratigráfica” não foi registrada, e foi substituída pela designação genérica "Formação Barreiras” (realidade geológica substituída indevidamente pela feição morfológica predominante em aerofotos). Esta seção e suas imediações devem ser destacadas como áreas de notável potencial de carga do Aquífero Beberibe, de forma que a grande barragem supridora do abastecimento d’água de João Pessoa (sistema Mamuaba-Gramame, da CAGEPA) tem sido a grande benefeciária e acumulador (subsidiado por realimentação constante) dessas águas, que aí são descarregadas na rede fluvial.

c. Ligação PB-016- (quilômetro 48 da BR-230) - para Pedras de Fogo (PB-910), cruzando sucessivamente os rios Mumbaba, Mamuaba e Gramame

Esta é a linha que atravessa a parte sul o "alto estrutural” chamado "Horste do Tabuleiro das Lagoas”, que é a área clássica dos tabuleiros ao longo da BR-230 (rodovia que liga João Pessoa ao interior da Paraíba), entre os quilômetros 42 e 62 desta rodovia. Esta seção que corta ao meio o "baixo estrutural” WSW-ENE (Rio Mamuaba) da parte ocidental da sub-bacia, onde a Formação Beberibe apresenta grandes espessuras (>150 m) e onde estão as maiores cotas regionais, com máximo de $212 \mathrm{~m}$, na torre da Embratel, no cume do domo topônimo, 10 km a nordeste de Pedras de Fogo.

Este contexto estrutural e estratigráfico distinto, situado entre os altos cursos dos rios Mumbaba (ao norte e noroeste) e Gramame (ao sul) está controlado por falhamentos - (observáveis no campo e na perfilagem geofísica) - que alinham os cursos d’águas regionais (Mumbaba, Mamuaba, Gramame, de direção aproximadamente esteoeste, com extraordinária repercussão na paisagem fisiográfica. Alguns outros falhamentos gravitacionais nortesul (Rio Grilo, Jangada) condicionam o espessamento da Formação Beberibe, no sentido do litoral. Exposições do embasamento (capeado pela “UPEN”) ocorrem nas principais linhas de drenagem mais profundas, acima mencionadas, merecendo destaque a zona dômica do alto curso do Gramame, área aqui designada “domo gnáissico de Santa Emilia”, com pequena parte apenas da cobertura da "UPEN” preservada.

Esta porção central do domínio mais ocidental da subbacia foi soerguida substancialmente (provavelmente em tempos Pós-Plioceno), de forma que a cobertura do Grupo Barreiras que poderia ter estado aí presente, foi exumada. Como já mencionado, o Grupo Barreiras passa a ocorrer destacadamente apenas nas zonas do terraço estrutural mais a leste (próximo domínio a ser descrito).

Toda a área deste domínio ("graben do Rio Mamuaba”) é muito importante do ponto de vista hidrogeológico, 
pois é a zona preferencial de carga do aquífero Beberibe que é constantemente drenado pelos seus efluentes principais (Mumbaba, Mamuaba e Gramame).

Como será discutido, este percurso completo realizado da PB-016 e da PB-910 (da BR-230 para També, via Giasa) permite assim cruzar o graben do Rio Mamuaba, mas também os dois altos que o delimitam: ao norte, o alto estrutural do Tabuleiro das Lagoas e ao sul-sudeste, o "alto estrutural de Ciaisa”.

As áreas dômicas de Santa Emília (ao norte de Pedras de Fogo, com exposição do embasamento) e o da Torre da Embratel (totalmente estruturado nos arenitos da Formação Beberibe), assinaladas no esboço geológico (Figuras 1 e 4) estão alinhados com step overs da ramificação para leste do lineamento Congo-Coxixola, conforme mostram alguns dados aerogeofísicos inéditos. É provável (dependendo de estudos adicionais) que estas áreas dômicas venham expressar estruturas do tipo push up ligadas com ativações tardias deste lineamento complexo e que apresenta muitas ramificações (splay out) na sua porção mais oriental.

\section{d. Rodovia BR-101 - trecho entre Goiana e João Pessoa}

Esta rodovia federal principal mostra seu traçado aproximadamente longitudinal à passagem de dois domínios estruturais muito nítidos da Sub-bacia de Alhandra. Para oeste, o domínio das estruturas basculadas (grabens e horstes acima descritos), e para leste (sentido do litoral) começa o domínio monoclinal Conde-Caaporã, onde a Formação Beberibe é gradativa e suavemente flexionada. Esta unidade está exposta ainda em alguns trechos mais rebaixados da rodovia da BR-101, e a partir daí passa a ocorrer em subsuperfície mergulhando para leste e sudeste. Esta mudança para a estruturação monoclinal condiciona, então, as primeiras exposições mais para leste das demais unidades cretáceas e paleogênicas (Gramame e Maria Farinha) e do Grupo Barreiras (neogênico), ali sobreposto e preservado e formando tabuleiros cada vez mais francos e íntegros no sentido do litoral (onde termina em falésias muito bonitas).

Apenas neste domínio pericosteiro, para leste e sudeste da BR-101, a litoestratigrafia da sub-bacia fica completa, consoante se pode ver no campo (e da análise de dezenas de poços profundos vide Figuras 3 a 5) de diversos objetivos. E é nesta parte mais baixa do terraço monoclinal Conde-Caaporã (e no Graben de João Pessoa) que o Grupo Barreira (e alguns depósitos Pós-Barreiras) ocorre em plenitude, terminando em linha de falésias de dezenas de quilômetros ao longo do litoral, de Pitimbú para o norte.

A discriminação acima se faz necessária, tendo em vista que em grande parte, as áreas de ocorrência da Formação Beberibe e de depósitos sedimentares quaternários (em muitas destas áreas discriminadas) foram cartografadas como sendo do Grupo Barreiras.

\section{OS POÇOS TUBULARES}

Já foi comentado o acervo de dados de poços tubulares na área investigada, a grande maioria deles constante dos catálogos da Costa Consultoria, Acquatool e SIAGAS/CPRM, sendo possível estimar mais de dois mil poços, face à demanda humana e industrial por água subterrânea. Foi feita uma seleção rigorosa e observação nos poços mais profundos, nos seus perfis descritos (em geral baseados em amostras de calha) e na situação geológica de campo, com o objetivo de embasar da melhor forma as seções geológicas apresentadas (Figuras 3 a 5).

Apesar de nem sempre ser possível se contar com o perfil litológico descrito ou suficientemente descrito, o uso destes dados é imprescindível. Estes poços também foram cotejados nos perfis de eletrorresistividade, feitos pela equipe do Departamento de Minas do Centro de Tecnologia da Universidade Federal de Pernambuco, acompanhando a realização do presente trabalho, e em etapas prévias (outros projetos). Alguns destes poços foram referências para a obtenção do mapa geofísico da Figura 2.

Na Tabela 3, foram listados alguns dos principais poços (seria impossível reproduzir todo o acervo) que serviram aos propósitos deste trabalho, havendo alguns casos em que a perfuração perfilou todo o pacote sedimentar (desde sedimentos Pós-Barreiras) e entrou no substrato Pré-Cambriano, onde indícios de crosta ferruginosa ("UPEN” ?) foram registrados em grandes profundidades (casos dos poços de Marés - ca. 250 m, e Buraquinho, 350 m), o que é surpreendente.

\section{INVESTIGAÇÃO GEOFÍSICA - ELETRORRESISTIVIDADE}

Um perfil de eletrorresistividade ao longo da BR-101 já existia nos acervos do Departamento de Engenharia de Minas da UFPE, que fora objeto de análise e interpretação por Feitosa et al. (2002). Para complementar (ao mínimo) o acervo de dados levantados na sub-bacia, e para amparar os dados nas seções longitudinais e assim, para melhor subsidiar a proposição da compartimentação tectônica (item a seguir), foi realizada mais uma campanha de eletrorresistividade, do sul de També, em Pernambuco para o norte, até a BR-230. Ou seja, ao longo do perfil “c”) do item acima (partes da PB-016, PB-910 e PB-032), acima descrito, cruzando o graben do Rio Mamuaba, e parte dos seus horstes delimitantes a sul (També) e a norte (Tabuleiro das Lagoas), sob o comando do Prof. Edilton Feitosa, da UFPE, e do que já apresentado em resumo em simpósio regional (Brito Neves et al., 2005b).

A título de investigação preliminar foram feitas as seguintes medições de resistividade elétrica (quadripolo 
Tabela 3. Dados de poços (selecionados para os cortes geológicos) agrupados por área/domínio. 0 bs: SPA = sedimentos de praia, aluviões, unidades Pós-Barreiras; Kg = Formação Gramame; KBe = Formação Beberibe; TTB = Grupo Barreiras.

\begin{tabular}{|c|c|c|c|c|c|c|c|c|c|}
\hline Poço & Coordenadas & $\begin{array}{l}\text { Cota } \\
(\mathrm{m})\end{array}$ & $\begin{array}{l}\text { Prof. } \\
(\mathrm{m})\end{array}$ & $\begin{array}{l}\text { Solol } \\
\text { SPA }\end{array}$ & TTB & Kg & $\mathrm{KBe}$ & Embas. & $\begin{array}{c}\text { Empresa } \\
\text { Perfuradora }\end{array}$ \\
\hline Grenville & $9200000-261000$ & 105 & 27 & 7 & - & - & 20 & & Hidrotec \\
\hline Massang. II & $9204688-265159$ & 103 & & 1 & - & - & 40 & 9 & - \\
\hline Massang. III & $9202200-265933$ & 100 & & 1 & - & - & 34 & 5 & - \\
\hline Mineral Platina & $9209018-278258$ & 80 & 72 & 6 & & & 66 & & Construpoços \\
\hline SPA/Miner. & $9209546-278983$ & 81 & 70 & 2 & & & 68 & & - \\
\hline SPA/Cristal & $9209546-278983$ & 81 & 124 & 2 & & & 20 & 2 & Hidrotec \\
\hline Alpargatas & $9212068-280272$ & 77 & 96 & & & & 96 & & Polipoços \\
\hline Alpargatas & $9212070-280275$ & 77 & 96 & & & & 96 & & Poçorese \\
\hline Alto Boa Vista & $9211000-286000$ & 55 & 300 & & 18 & 47 & 190 & & DNOCS \\
\hline TERMAS & $9208530-287870$ & 60 & 323 & & 36 & - & 287 & & CORNER \\
\hline Alto Mateus I & $9209748-289158$ & 38 & 300 & & 26 & - & 274 & & - \\
\hline Alto Mateus II & $9211032-888348$ & 41 & 300 & & 21 & - & 279 & & - \\
\hline Cruz Armas & $9210400-291200$ & 42 & 328 & & 28 & 59 & 241 & & CAGEPA \\
\hline Pavilhão do Chá & $9212372-291920$ & 65 & 210 & & 30 & 42 & 138 & & - \\
\hline Buraquinho & $9210844-294549$ & 16 & 373 & & 14 & 56 & 303 & 9 & CONESP \\
\hline UNIMED & $9211600-295000$ & 42 & 150 & & 43 & 33 & 74 & & - \\
\hline Cabo Branco & $9211600-296000$ & 50 & 252 & & 47 & 9 & 196 & & CAGEPA \\
\hline Altiplano & $9211000-297300$ & 54 & 300 & & 80 & 55 & 165 & & CAGEPA \\
\hline Hotel Igatu & $9211874-298500$ & 5 & 130 & 10 & 18 & 60 & 42 & & - \\
\hline Nossa Sra. Livramento & $9220700-289500$ & 7 & 342 & 1 & 80 & & 261 & 1 & CONESP / PC-03-II A \\
\hline Pedras de Fogo & $9181400-267000$ & 190 & 50 & - & - & - & 48 & 2 & CDRM \\
\hline Posto Marcação & $9181806-272290$ & 162 & 70 & - & - & - & 68 & 2 & CDRM \\
\hline GIASA I & $9186750-276058$ & 68 & 63 & 4,5 & - & - & 58,5 & & PROPOÇO \\
\hline GIASA II & $9186750-276000$ & 68 & 94 & 3 & - & - & 91 & & PROPOÇO \\
\hline Muribara & $9184184-275170$ & 130 & 120 & 4 & & & 116 & & CDRM \\
\hline Caaporã 2 & $9168770-291680$ & & 20 & & & & 20 & & CPRM \\
\hline Caaporã 3 & $9168870-292750$ & & 21,16 & & & & 21,16 & & CPRM \\
\hline Caaporã Sede I & $9169508-287000$ & 70 & 263 & - & 110 & - & 151 & 2 & HIDROGESP \\
\hline Caaporã Sede II & $9169508-287000$ & 70 & 220 & - & $60 ?$ & - & 159 & 1 & CONESP \\
\hline Caapora Sede III & $9169508-287000$ & 70 & 183 & - & $25 ?$ & - & 158 & 1 & - \\
\hline Pitimbu & $9173700-300412$ & 3 & 165 & 29 & - & 76 & 60 & & CDRM \\
\hline Pitimbu & $9173700-300412$ & 5 & 392 & 12 & 18 & 71 & 289 & 2 & CONESP / SN 01 II A \\
\hline Mata Redonda & $9188000-285000$ & 71 & 200 & 30 & - & - & 170 & & GEOHIDRO \\
\hline Mata Redonda & $9185400-285200$ & 70 & 100 & $? ?$ & - & - & $100 ?$ & & HIDROTEC \\
\hline GDF/Tabatinga & $9191000-288512$ & 65 & 120 & & 66 & 54 & - & & - \\
\hline Garapu & 9187984-288512 & 32 & 243 & - & - & - & 243 & & CONESP / Pz-01-2a \\
\hline
\end{tabular}

AMNB linear simétrico Schlumberger): 14 sondagens elétricas verticais, linha $\mathrm{AB}$ entre 1.400 e $3.000 \mathrm{~m}$ (proximidades da BR-101); duas sondagens elétricas adicionais semelhantes (nordeste de També); $20 \mathrm{~km}$ de perfis de resistividade, utilizando linha AB de $2.800 \mathrm{~m}$ e espaçamento de $700 \mathrm{~m}$ entre estações, todos estes últimos ao longo da PB-910.
O conjunto de todas as medidas permitiu a obtenção de um mapa de resistividades aparentes, esquematicamente figurado em anexo (Figura 2), que foi apoiado pelos dados geológicos de campo e pelos dados de alguns poços profundos, como o de Garapu (coordenadas 288512/9187984), cerca de 4 km a leste de Mata Redonda, 
sede da Policia Rodoviária Federal), que contém excelente perfilagem (Feitosa et al., 2002).

Em todas as SEVs acima indicadas, o embasamento Pré-Cambriano se manifestou eletricamente, traduzido por um ramo terminal bem definido, ascendente a $45^{\circ}$. O conjunto de arenitos da Formação Beberibe se manifesta como um horizonte basal muito condutivo e de grande magnitude, uma vez que estes sedimentos constituem a maior parte do preenchimento estratigráfico da bacia (no graben do Rio Mamuaba e na monoclinal de Conde-Caaporã a serem descritos abaixo). Considerando este comportamento, foi adotada a linha $\mathrm{AB} / 2$ igual a 1.400 no perfil de resistividade realizado, para obtenção das resistividades aparentes compatíveis com aquelas obtidas nas sondagens elétricas.

No esquema apresentado, curvas de resistividade aparente (ohm.m) foram traçadas, sendo considerado que aquelas de maior valor relativo (e.g., 120 ohm.m) significam que o “embasamento cristalino" está mais raso, e curvas apontando menor resistividade aparente (e.g., 60 ohm.m), por seu turno, indicam profundidades maiores para o embasamento.

De certa forma, o conjunto de todas as resistividades aparentes obtidas, disposto em planta, mostrou notável coerência com as observações geológicas de campo, favorecendo o apoio mútuo e a interpretação das maiores feições estruturais (compartimentação), a serem propostas a seguir.

\section{COMPARTIMENTAÇÃO TECTÔNICA PROPOSTA}

O trato conjunto dos dados da geologia de superfície e de subsuperfície (poços tubulares e levantamento geofísico) permite propor preliminarmente compartimentos estruturais, alinhados na direção NNE-WSW, a serem tratados a seguir, e que têm o respaldo dos cortes geológicos apresentados (Figuras 3 a 5).

\section{Alto També-São Miguel de Taipú-Riacho Curimataú}

Este alto, de direção norte-noroeste, é o primeiro a ser comentado, posto que limita a sub-bacia para oeste. Compreende todo o médio e alto curso do Rio Mumbaba, correspondente a toda área soerguida já identificada acima, item "a” (PB-082 e sua ligação para Oratório), incluindo parcela mais ocidental do item "b" (parte da PB-030), onde o embasamento aflora extensivamente (localmente com sua cobertura "típica" da UPEN). Na verdade, este "alto" assim delineado pela geofísica está reunindo, da dorsal de També para São Miguel de Taipu, que delineia o limite ocidental da sub-bacia e assim a separando do Graben de Cariatá, ou seja, numa síntese, trata-se de uma zona de flexura do embasamento que interrompe (soerguido fra- camente) a continuidade para leste do Graben de Cariatá e delineia o limite mais ocidental da sub-bacia.

Na porção central desta estrutura, no alto curso do Rio Mumbaba, seus tributários primordiais (riachos Seco, Gavião, Coqueirinho) se distribuem de forma centrífuga, configurando e circunscrevendo uma forma dômica digna de nota.

\section{Horste Tabuleiro das Lagoas ("Planalto da BR-230")}

Este "alto estrutural" ou horste está sendo proposto em decorrência da conjugação dos trabalhos de superfície, geológicos e geomórficos, pelas cotas do contato embasamento/"UPEN" - Formação Beberibe que foram diligentemente palmilhados, pelos dados de eletrorresistividade e pelos dados de poços tubulares. Neste domínio da BR-230, conhecido como "Planalto", as cotas topográficas perfazem um notável platô de cerca de 100 m ( \pm 10 m) suavemente inclinado para leste. Neste domínio estão destacadamente as menores possanças sedimentares $(<40 \mathrm{~m})$, conforme pode ser visto nos poços tubulares (Massangana II e III, Grenville, entre outros), e este contingente parece ser exclusivo da Formação Beberibe e de algumas coberturas mais recentes (uma perfilagem melhor dos poços seria necessária para definir) (Figura 7).

Por toda periferia deste segmento de planalto, ao norte (Cafundó, Estiva, Reis), oeste (quilômetro 62) e sul (sul de Massangana III, Assentamento Tatiane, Alecrim etc.) do topo deste "planalto"/tabuleiro para o contato com o embasamento (sempre acobertado pelo "UPEN") as diferenças de cotas são na maioria inferiores a $30 \mathrm{~m}$, ratificando as observações dos poços. De forma complementar, no perfil de eletrorresistividade N-S realizado, a elevação do embasamento neste segmento aparece de forma conspícua (Figura 2; Figura 3 - Tibirizinho-Massangana).

Em função natural da identificação desta porção elevada do embasamento, ficam definidos os vários "baixos" adjacentes: ao sul (Graben Mamuaba), ao norte (graben do baixo Rio Paraíba) e a leste (Sistema de grabens da grande João Pessoa).

\section{Graben do Rio Mamuaba}

O "Baixo/graben do Rio Mamuaba", compreendendo toda a área do vale do Rio Mamuaba e do baixo Rio Mumbaba (correspondente em grande parte ao trecho cortado pela PB-910, item "c" acima) que se comporta como um graben de direção geral NNE-SSW, situado do norte de Pedras de Fogo para a confluência Mamuaba-Gramame, onde estão preservadas as maiores espessuras da sub-bacia (são estimados pelos dados geofísicos até $300 \mathrm{~m}$ para a Formação Beberibe) (Figura 8). 


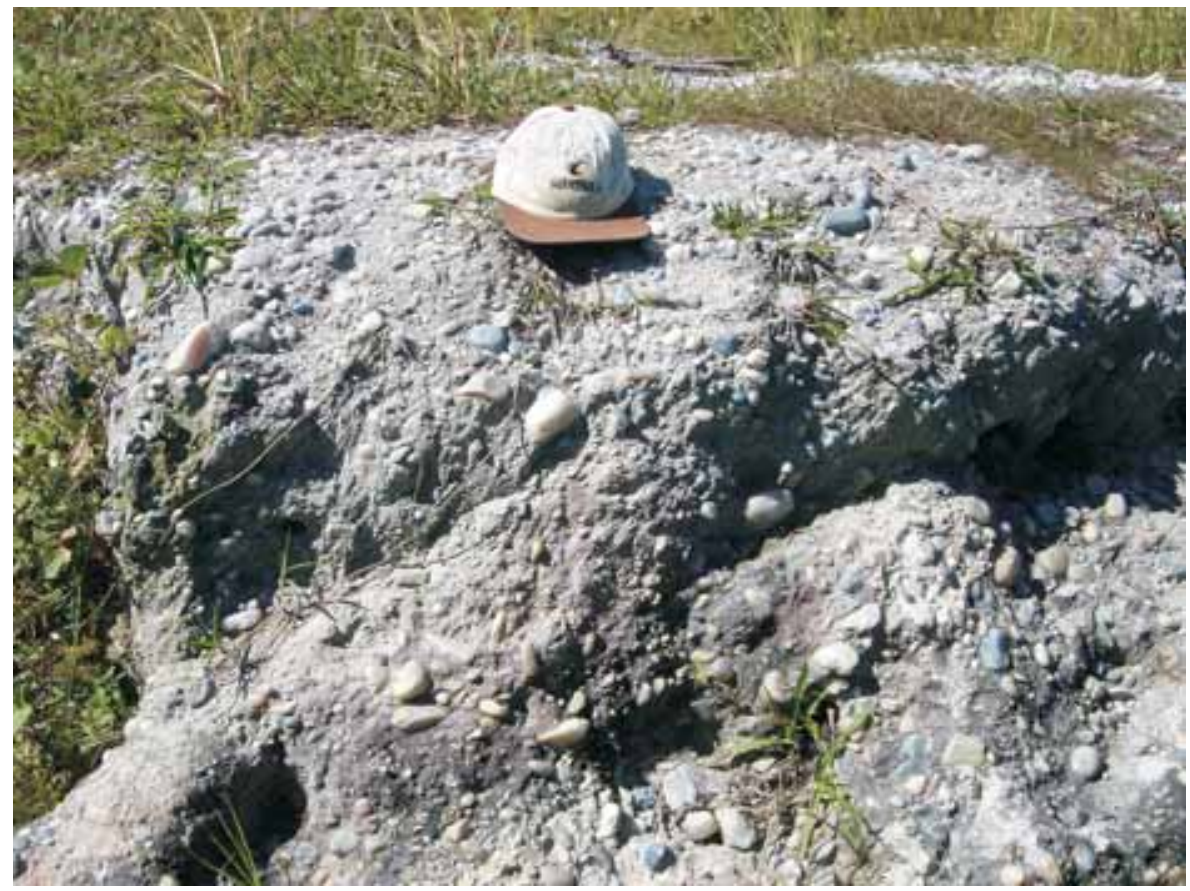

Figura 7. O paraconglomerado basal (oligomito) da Formação Beberibe, aflorando no vale do Riacho Arrombado na BR-230 (quilômetro 58,6) no Horste do Tabuleiro das Lagoas.

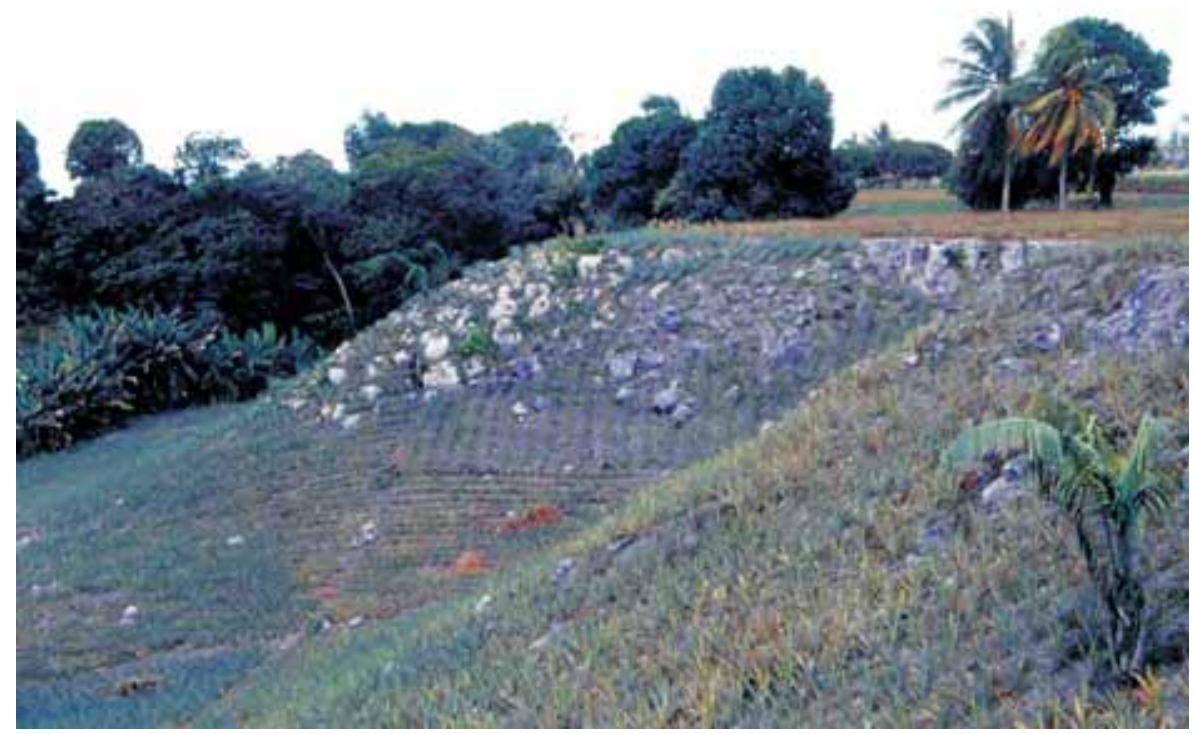

Figura 8. Foto panorâmica da escarpa mais ocidental da Formação Beberibe, 35 km SSW de João Pessoa, na vertente do Rio Mumbaba. O rio corre sobre o embasamento (cota 90 m) que está capeado pela "UPEN" (de 90 a 110 m), e esta, pela Formação Beberibe (em cotas desde 110 a $172 \mathrm{~m}$ ). 
Este graben já havia sido observado com os dados do mapeamento de campo, e nele está desenvolvida uma interessante estrutura circular da Formação Beberibe, com drenagem centrífuga conspícua (tributários do Gramame e Mamuaba) e em cujo ápice central está o ponto culminante da sub-bacia, na torre da Embratel, com 212 m (Figura 9). Observar o fato de que no domínio de maior intensidade da tectônica subsidente está a mais elevada expressão morfológica da sub-bacia.

Como contraponto desta estrutura dômica elevada, deve ser consignada a presença de uma elevação similar (forma subelíptica) do substrato cristalino, no "Domo de Santa Emilia”, que perfaz o limite sudoeste do graben principal, situado ao norte de Pedras de Fogo, e de onde partem os tributários fundamentais do alto curso do Rio Gramame. O "Domo da Embratel" (para E-NE) e o "Domo de Santa Emília” (para W-SW) praticamente se tocam, e suas causas e inter-relacionamento imprescindem de uma investigação de subsuperfície mais aprofundada.

Algumas imagens inéditas de aerogeofísica (Mapa de Contorno do Campo Magnético total da CPRM - Serviço Geológico do Brasil) sugerem que estes domos (prováveis estruturas push up) estão relacionados com ativações tardias do splay out do Lineamento Congo-Coxixola. Mas, outras possibilidades existem e o tema está em aberto.

\section{Graben do Baixo Rio Paraíba (Várzea do Paraíba)}

Ao norte do “alto" do Tabuleiro das Lagoas, marcado por uma linha de falha normal de direção W-SW/E-NE que passa ao longo das localidades de Estiva, Reis e Tibiri (aproximadamente perlongado à estrada de ferro da RFN) e que deve ir até a linha de costa (parte norte da Praia de Tambaú) se situa o Graben do Baixo Paraíba. A partir desta linha de falhas, as cotas do embasamento caem bruscamente por mais de $50 \mathrm{~m}$ (de $80 \mathrm{~m}$, ao sul, para valores até inferiores a $20 \mathrm{~m}$ ), e aparecem alocados os depósitos do Grupo Barreiras e dos sedimentos da planície aluvial. O limite norte deste graben é colocado provisoriamente subparalelo ao norte, tangenciando o curso do Rio Engenho Novo (afluente do Paraíba), balizando e limitando ao norte a ampla planície aluvial (até $5 \mathrm{~km}$ de largura). Faltam dados concretos de subsuperfície para aclarar este contexto, embora alguns dados preexistam (ainda insuficientes) (Figura 10).

\section{Sistema de grabens da Grande J oão Pessoa}

Para leste da estrutura do Tabuleiro das Lagoas, a partir da borda oriental do "planalto", a altura do meridiano de $35^{\circ} 00^{\prime}$, próximo à divisa das folhas de Sapé e João Pes- soa (escala de 1/100.000), começa o sistema de falhas que deu origem ao graben escalonado para leste, para Bayeux e João Pessoa. Isto pode ser acompanhado pela sucessão de poços tubulares nas localidades de Platina, Cristal, Alpargatas, Alto Mateus etc., até Buraquinho e outros poços da Praia de Tambaú, conforme pode ser visto na Tabela 3 e na Figura 3. Bruscamente, a partir deste ponto (Planalto/Tabuleiro das Lagoas) para leste, o substrato cristalino é abatido em cota, a Formação Beberibe se espessa (alcançando valores de até 270 m em Alto Mateus para 303 m em Buraquinho), a Formação Gramame se faz presente, assim como o Grupo Barreiras atinge sua culminação em espessamento (e/ou preservação), com valores entre 30 e $80 \mathrm{~m}$.

O Grupo Barreiras não só atinge suas máximas espessuras na grande João Pessoa (muito recortado pelo ciclo erosivo atual) como a sua maior expressão cartográfica, entre os baixos cursos do Rio Gramame e Paraíba. A Figura 3 mostra este comportamento tectônico-estratigráfico geral, mas ela pode ser bastante melhorada, incrementando-se a escala e o número de poços tubulares a ser computado. No atual quadro, não fica claro se as interrupções (há vários poços onde ela não foi apontada/detectada) de ocorrência da Formação Gramame são por conta desta tectônica rúptil, ou devido a processos erosionais Pré-Barreiras (ou ainda, se devido à baixa qualidade das informações de alguns poços).

\section{Horste Ciaisa}

Ao sul-sudeste do graben do Rio Mamuaba fica o "alto estrutural” subparalelo ao curso do Rio Gramame (que será chamado informalmente de horste de Ciaisa), que é acompanhado, também de forma subparalela pela parte oeste da BR-101, interceptando-o à altura da cidade de Conde .

Este alto estrutural já havia sido bem delineado, com dados da geofísica e de campo (vide Feitosa et al., 2002 e Brito Neves et al., 2005b), e ganhou novas evidências. Neste "alto estrutural", onde o embasamento foi soerguido e aflora descontinuamente (sob a Formação Beberibe), consoante a direção geral NNE-SSW, o que pode ser identificado/seguido desde o Rio Cupissura (sudeste de També) até as proximidades sudoeste de Conde. No quilômetro 103 da BR-101, na entrada da localidade de Pesque e Pague (pouco ao sul de Ciaisa), o substrato Pré-Cambriano soerguido por este "alto" aparece em superfície, capeado em parte pela "UPEN".

\section{Monoclinal Conde-Caaporã}

Para leste, uma das linhas de falha que delimitam o "alto estrutural" do Ciaisa, demarca e condiciona o aparecimento da estrutura monoclinal Conde-Alhandra-Caapo- 


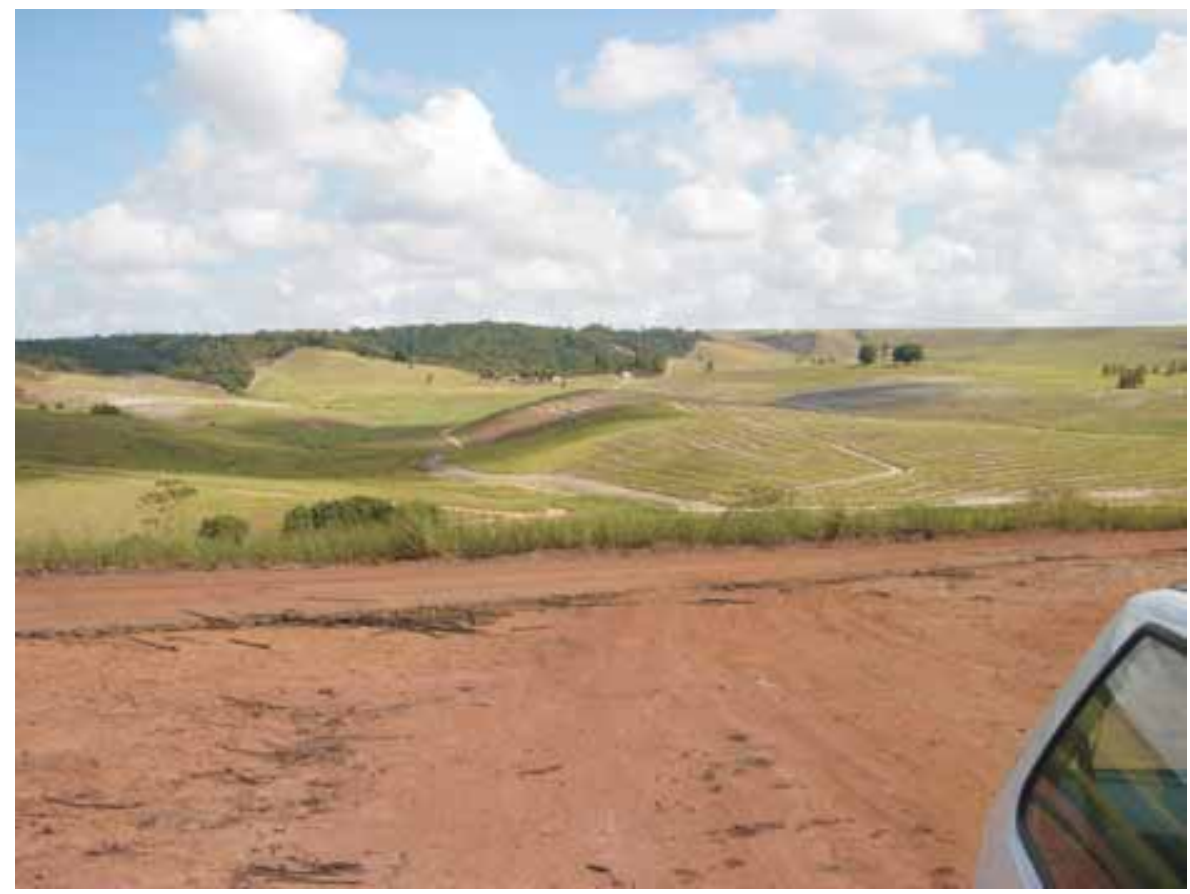

Figura 9. Foto panorâmica do Domo da Torre da Embratel, visto do sul, do Engenho Giasa. A Formação Beberibe, aparentemente sobreposta à "UPEN", suporta o domo que reporta as mais altas cotas da sub-bacia, com $212 \mathrm{~m}$.

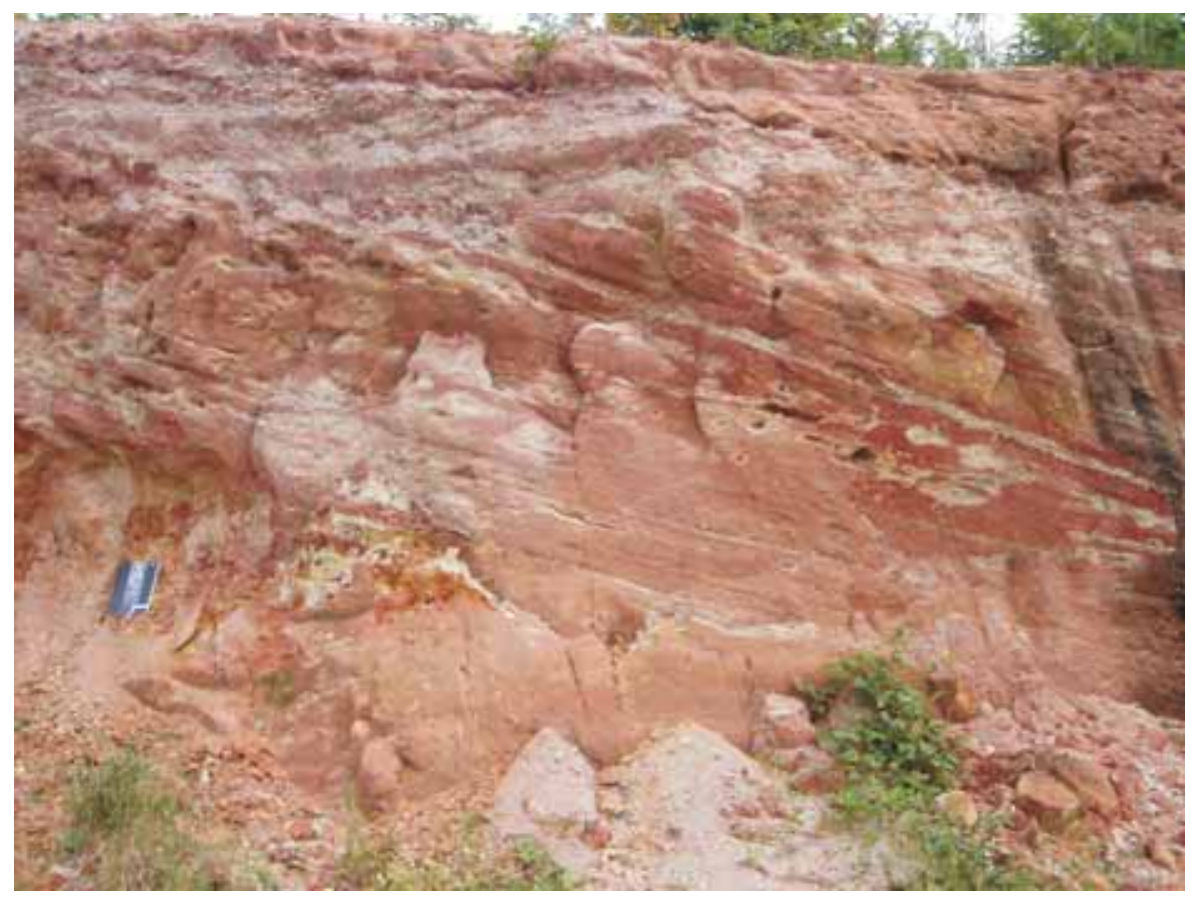

Figura 10. Os arenitos e conglomerados basais da Formação Beberibe discordantes sobre o embasamento (o qual é capeado pela "UPEN"), no Engenho Muguengue, no graben do Baixo Rio Paraíba. 
rã, que se desenvolve das imediações leste da BR-101 (e a esta rodovia se desenvolve subparalelo) para a faixa costeira, o que pode ser percebido francamente no levantamento geológico de campo. Este terraço estrutural das unidades litoestratigráficas plano-paralelas mostra inclinação muito suave para leste e para sudeste, exibindo o contato entre as formações Beberibe e Gramame com cotas entre 50 - $30 \mathrm{~m}$, e que chegam ao nível do mar (já próximas a zero) mais para sul e sudeste. Esta estrutura, e seu contexto litoestratigráfico, possui notável registro em dezenas de poços tubulares e em várias grandes pedreiras de calcário (Figuras 11 e 12).

\section{Outras estruturas afins no contexto regional}

O quadro observado e acima descrito (e cartografado, Figura 1) de estruturas rúpteis predominantes WNW-ESE, interceptadas por outros elementos estruturais NNW-SSE não se restringe à área mapeada, tendo um caráter mais regional que transcende aos estados do Rio Grande do Norte (para o norte) e para Pernambuco (ao sul), tendo sido objeto da análise de alguns trabalhos preexistentes, entre publicados e inéditos.

No norte da área, imediatamente ao norte do Graben do Baixo Paraíba, se situa um alto tectônico (horste), no chamado "Tabuleiro do Santana” (só pequena parte do mesmo está na Figura 1), que é cruzado pela BR-101, e no qual a Formação Beberibe está alçada a cotas próximas de 200 m. Este horste é sucedido mais para norte (fora da área do mapa) pelo Graben de Miriri-Sul de Mamanguape, o qual por sua vez é sucedido por um horste conspícuo (onde o embasamento aflora ostensivamente na vertente norte do Rio Mamanguape), chamado de Mamanguape-Itapororoca, de acordo com Brito Neves et al. (2007, 2008).

Para o sul da área, deve ser destacado que o graben do Rio Mamuaba (já discutido) é limitado para sul (já no Estado de Pernambuco) pelo amplo (cerca de $20 \mathrm{~km}$ de largura) "Horste Uruaé-Caricé”, cujo sistema de falhas começa em També - PE/Pedras de Fogo - PB (cidades contíguas da divisa Paraíba-Pernambuco). Em Pedras de Fogo predominam sedimentos (bloco abatido) e dentro de També aflora o embasamento (capeado pela “UPEN”). Nesta interação estrutural rúptil o embasamento se encontra milonitizado, sinalizando a probabilidade de herança tectônica (a partir do lineamento Congo-Coxixola). Por todo contexto ao sul de També, neste alto estrutural afloram ora rochas do embasamento (Complexo Sertânia), ora cobertos por remanescentes da "UPEN" e da Formação Beberibe. Neste alto de embasamento soerguido (e muito estruturado por falhamentos pré-cambrianos) há várias evidências de tectônica moderna, com basculamentos ostensivos da "UPEN", e a formação de estruturas dômicas alongadas nos vales dos

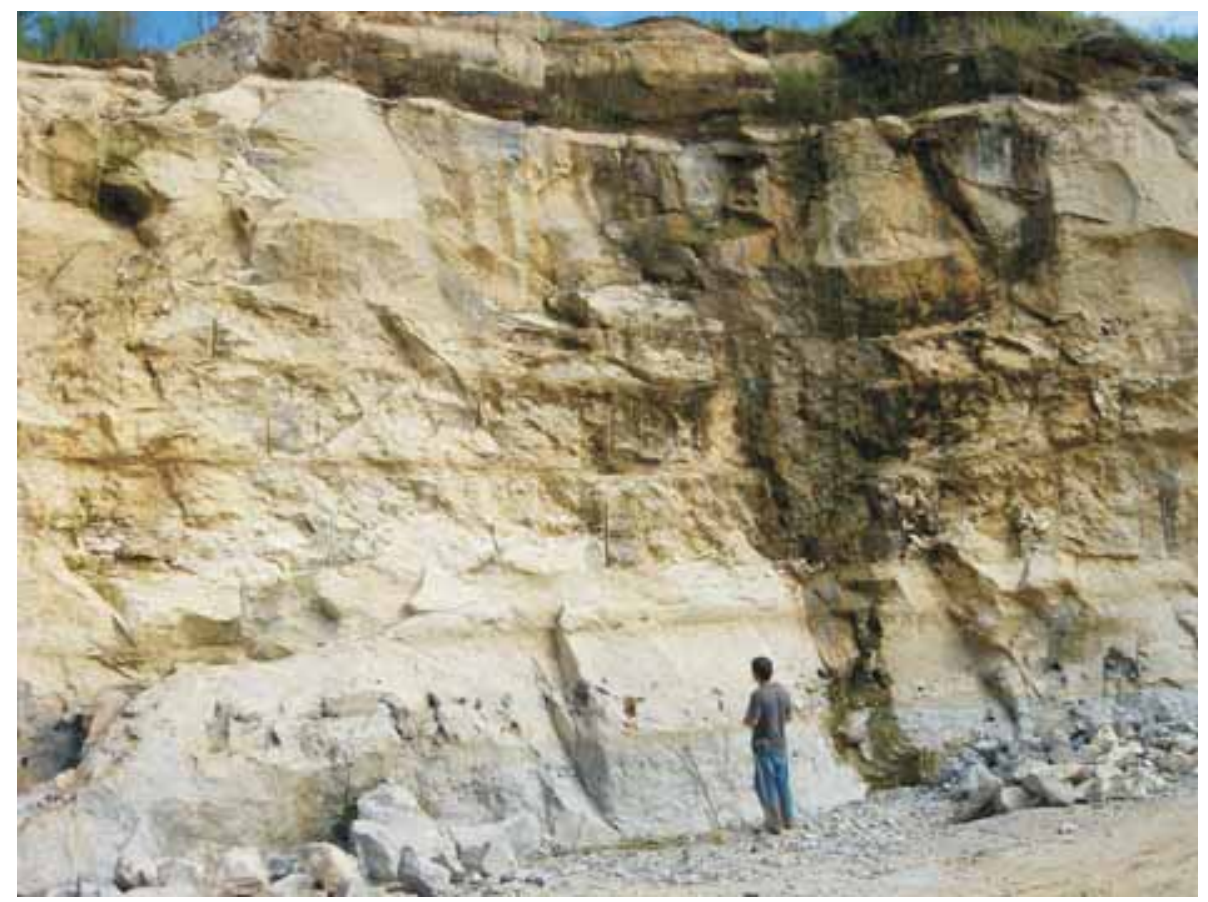

Figura 11. O s calcários da Formação G ramame aflorantes ostensivamente nas imediações leste da cidade de Alhandra, no contexto monoclinal Conde-Caaporã. 


\section{Geologia}

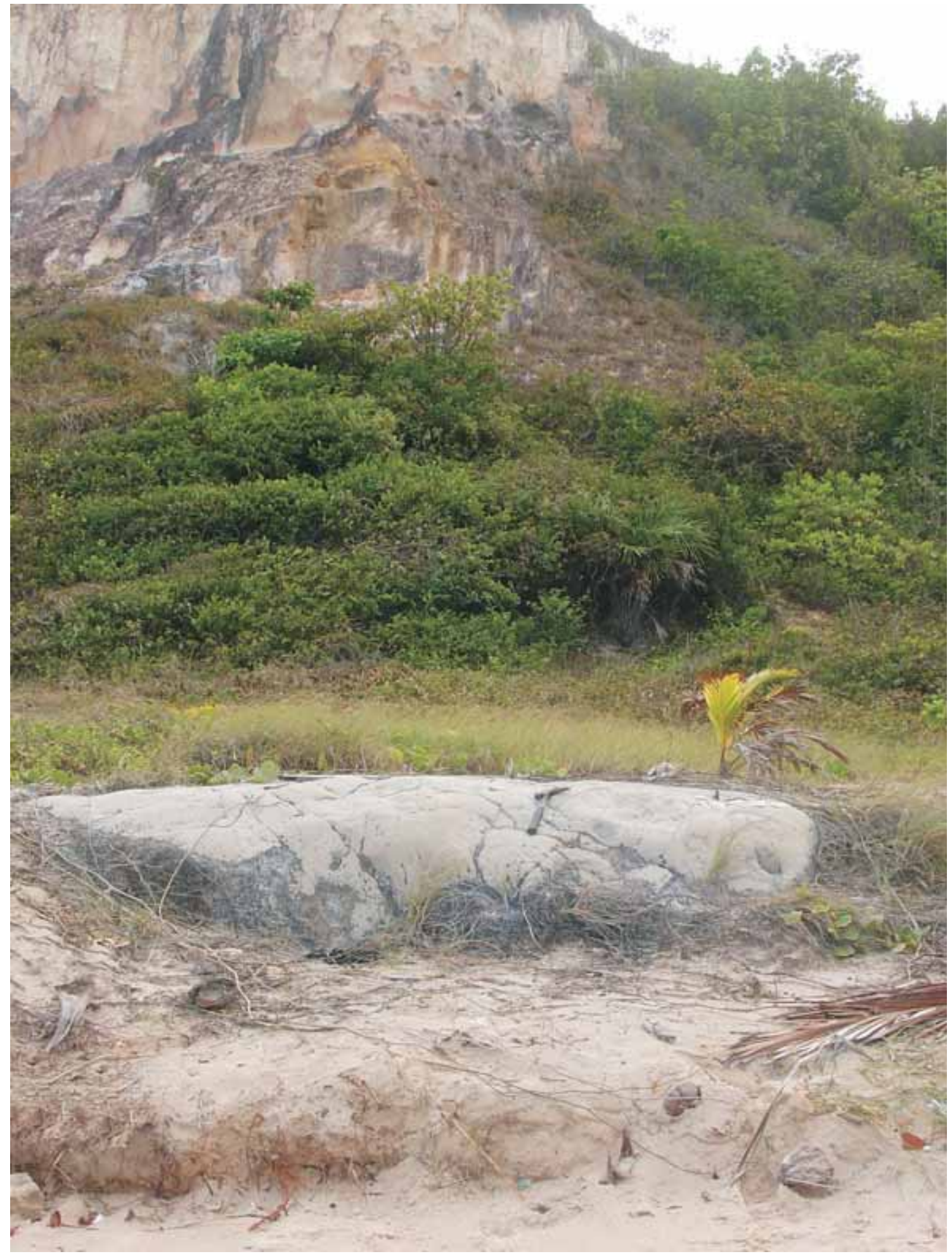

Figura 12. Na Praia de Tabatinga, pouco ao sul de Jacumã, a frente de escarpas do Grupo Barreiras (parte de cima da foto) disposta discordante sobre um dos raros afloramentos (on shore) da Formação Maria Farinha (parte debaixo da foto, onde está o martelo). 
rios Meirim-Muzumba Cupissura, em parte tentativamente figuradas no mapa anexo (Figura 1).

Delimitando ao sul do Horste Uruaé-Caricé, já no Estado de Pernambuco, foi recentemente definido um graben ao longo do Rio Goiana (Silva, 2006; Tavares et al., 2008) e há menções ao prosseguimento deste estilo (grabens e horstes em paralelo) mais para sul.

Para oeste da área mapeada, na chamada zona do agreste paraibano, a oeste da dorsal que foi chamada TambéSão Miguel de Taipú-Riacho Crurimataú e, portanto, mais distante da faixa costeira, esta tectônica rúptil está devidamente representada com os horstes de Boqueirão, o graben do Rio Cariatá e o horste que perlonga grande parte da divisa Paraíba-Pernambuco, que foram objetos de estudos e publicações recentes de Brito Neves et al. (2004) e Bezerra et al. (2008), e que são considerados trabalhos complementares (e foram os motivadores) do presente trabalho.

A discriminação da idade desta segmentação é problema em aberto, cabendo ainda um cotejo de investigação multidisciplinar. O início destes processos deve estar na parte inferior do Cretáceo ainda, a julgar pelos dados de Bezerra et al. (2008). Mas, há várias evidências de reativações, movimentações efetivas posteriores, inclusive mais jovens do que o Neógeno. Tanto do embasamento, cuja unidade guia de topo é a crosta "UPEN" (que o acompanha em suas diferentes cotas), como da Formação Beberibe (cuja unidade guia é o conjunto de conglomerados basais), como no próprio Grupo Barreiras (de idade do Mioceno) há várias evidências concretas de ampla movimentação vertical.

Sem considerar o mergulho natural do substrato, do interior para costa (que pode estar consorciado com falhamentos), nas seções longitudinais à sub-bacia, foi encontrada a "UPEN" em cotas de 120 - 130 m (valores mais altos) até valores mínimos de 25 - 20 m ("baixos estruturais") como Muguengue, na várzea do Paraíba, com vários outros domínios intermediários entre estes extremos. Como, normalmente, esta unidade (“UPEN”) está em cotas de 100 - 90 m, ela é uma ferramenta-guia interessante para observar as movimentações verticais do embasamento.

Sem considerar o mergulho natural da Formação Beberibe, do interior (cotas de 150 - 120 m, em geral, e excepcionalmente de $212 \mathrm{~m}$, na área dômica da Torre da Embratel, ao norte de Pedras de Fogo), para o litoral (cotas de 37 - 35 m em Garapu, cota de ca. 25 m e no contato com a Formação Gramame, próximo a Pitimbu), em perfis longitudinais à sub-bacia, há desníveis importantes. Os conglomerados basais da Formação Beberibe são encontrados, longitudinalmente em cotas cerca de $22 \mathrm{~m}$ (no Baixo Paraíba) e em cotas superiores a $70 \mathrm{~m}$, em várias localidades (na verdade entre 70 e $212 \mathrm{~m}$ nos diversos altos estruturais). Excepcionalmente, há algumas ocorrên- cias da Formação Beberibe em cotas excepcionalmente baixas, destoantes do padrão geral de "amplas chapadas" (> $70 \mathrm{~m}$ ), que precisam ser melhor investigadas. Deve ser citado, por exemplo, os casos das depressões de "Hélio Empreendimentos”, no quilômetro 100 da BR-101, onde cotas da ordem de $35 \mathrm{~m}$ são comuns (ainda sem explicação ou compreensão devidas) no topo dos arenitos.

As movimentações tectônicas afetando o Grupo Barreiras são as mais conspícuas no levantamento de campo, e ao longo da costa nas suas falésias. Trata-se de uma unidade que é comum na constituição dos tabuleiros, sempre em cotas relativamente mais baixas que aquelas da Formação Beberibe (ou seja, cotas predominantes entre 60 e 100 $\mathrm{m})$, e constituem domínios absolutamente mais dissecados por erosão. Na praia de Nossa Senhora do Livramento (no nordeste da área mapeada) foram observados desníveis superiores a $50 \mathrm{~m}$ (da cota de $70 \mathrm{~m}$ para a de $18 \mathrm{~m}$ ) no topo da unidade, de um afloramento para outro.

Vários outros autores, em trabalhos anteriores (como Bezerra et al., 2001; Furrier et al., 2006) já focalizaram esta tectônica moderna atuante na área, sem terem obtidos valores concretos de idade. Este necessário levantamento geocronológico está sendo feito no presente (dentro de um contexto multidisciplinar de investigações já mencionado).

\section{EXCERTOS CONCLUSIVOS}

1. A designação de Sub-bacia de Alhandra está sendo utilizada por razões meramente descritivas (entre os rios Goiana e Mamanguape), mas não há respaldo tectônicoestratigráfico suficiente para estes tipos de subdivisões na Bacia Pernambuco-Paraíba. A Sub-bacia considerada é, na verdade, parte indivisível de um todo.

2. No contexto litoestratigráfico desta sub-bacia devem ser incluídos e considerados os terrenos do seu embasamento (Rio Grande do Norte/RGN, Alto Pajeú/TAP, Alto Moxotó/TAM, e Rio Capibaribe/TRC, de norte para o sul) e de suas descontinuidades estruturais maiores, pois há evidências de heranças tectônicas concretas a considerar, para com os terrenos e seus limites (inclusive porque há limites complexos, fasciculados).

3. Deve ser considerado na coluna litoestratigráfica regional, a Unidade Pedoestratigráfica Engenho Novo (UPEN), que capeia as unidades do embasamento. Embora a mesma transcenda a área (da folha Guarabira para a folha Limoeiro), ela evidencia notável período da evolução geomórfica regional que foi encoberto pela instalação da Sub-bacia. A sua idade é problema em aberto, que carece investigação.

4. O Grupo Barreiras foi extensivamente "mapeado" mediante conceitos aerofotogeológicos levando a vários 
equívocos. Além de dados de campo, há dados de minerais pesados que permitem separar o Grupo Barreiras da Formação Beberibe sotoposta. E esta distinção pode ser aprimorada, novas ferramentas de distinção devem ser procuradas. Uma revisão nos mapas preexistentes (de diferentes escalas) se faz necessária.

5. Diante do exposto acima, devem ser reiteradas as exposições ostensivas da Formação Beberibe e o seu registro em dezenas de poços tubulares. A exemplo do panorama agora traçado para o sul da Paraíba, os contextos mapeados no norte da Paraíba, no Rio Grande do Norte e de Pernambuco carecem ser revistos.

6. A Sub-bacia de Alhandra foi atingida por densa tectônica rúptil extensional, com direções WSW-ESE e NNW-SSE, cujos processos demandam vários estudos complementares e o respaldo do estudo de subsuperfície (poços tubulares, métodos geofísicos e outros). Na presente instância do conhecimento, fica difícil separar esta tectônica daquela que gerou o Graben de Cariatá, definido mais a oeste. Movimentos direcionais estão sugeridos na formação de vários domos, expondo o embasamento e/ou marcados nas coberturas.

7. A terminação oriental do Lineamento Congo-Coxixola apresenta uma série de ramificações (splay out complexo) com linhas de direções NE-SW, que passam entre Juripiranga - PB e També - PE), e há várias indicações de ativação destas linhas de falha afetando a cobertura sedimentar, definindo altos e baixos estruturais, zonas dômicas etc.

8. Alguns altos estruturais, como os de També-São Miguel de Taipú-Riacho Curimataú (NNW) e de Ciaisa podem corresponder a simples flexuras lineares do embasamento, sem disjunções rúpteis marcantes. O mapeamento da "UPEN" foi elemento importante para determinar muitos dos altos, posto que há uma ligação estreita entre ela e o topo embasamento, em diferentes terrenos pré-cambrianos.

9. A monoclinal simples sempre retratada para a Subbacia de Alhandra só ocorre na borda sul-oriental da Paraíba (e em parte da fronteira mais oriental com Pernambuco). Todo o contexto restante é fortemente estruturado, com notória tectônica de blocos, ainda que conhecida e descrita apenas no nível qualitativo.

10. Estas características geológicas gerais, observadas em mapa e apontadas para a subsuperfície têm repercussão grande e imediata no estudo e exploração dos recursos hídricos e minerais. A área de exposição (carga) do Aquífero Beberibe é dezenas de vezes superior àquela configurada antes.

11. O conhecimento da Sub-bacia de Alhandra é absolutamente incipiente. Muitos termos do conhecimento geológico de superfície e subsuperfície são insuficientes ainda. O conhecimento geológico deve ser considerado iniciado e o conhecimento geofísico está praticamente em aberto.

\section{REFERÊNCIAS BIBLIOGRÁFICAS}

ACQUATOOL CONSULTORIA. Avaliação das Potencialidades, Disponibilidades e Condições de Explotação das Águas Subterrâneas da região da Grande João Pessoa. Recife: Acquatool, 2005. (Relatório Final da Primeira Etapa dos Serviços, vol 1 e 2, capítulos 1 a 6. para o Projeto da Usina Termo-Elétrica da Paraíba).

ALHEIROS, M. M.; LIMA FILHO, M. F.; MONTEIRO, F. A. J.; OLIVEIRA FILHO, J. S. Sistemas deposicionais na Formação Barreiras no Nordeste Oriental. In: CONGRESSO BRASILEIRO DE GEOLOGIA, 35., 1988, Belém. Anais... Belém: SBG, 1988, v. 2, p. 753-760.

BARBOSA, J. A; LIMA FILHO, M. Aspectos estruturais e estratigráfiicos da Faixa Costeira Recife-Natal; observação em dados de poços. Boletim Geociências da Petrobrás, v. 14, n. 2, p. 287-306, 2006.

BARBOSA, J. A.; SOUZA, E. M.; LIMA FILHO, M. F.; NEUMANN, V. H. A Estratigrafia da Bacia Paraíba: uma reconsideração. Estudos Geológicos, CTG-UFPE, v. 13, p. 89-108, 2004.

BARBOSA, J. A.; SOUZA, E. M.; LIMA FILHO, M. F.; NEUMANN, V. H. Estratigrafia da Bacia Paraíba, NE Brasil: uma nova proposta a partir da estratigrafia de seqüências.. In: CONGRESSO DE PESQUISA \& DESENVOLVIMENTO EM PETRÓLEO E GÁS DA UFPE, 1./REUNIÃO DE AVALIAÇÃO DO PRH/ANP/MCT, 3., 2003, Recife. Boletim de Trabalhos...Recife, 2003, p. $100-108$.

BARBOSA, J. A.; SOUZA, E. M. de; LIMA FILHO, M.; NEUMANN, V. H. The Stratigraphic Evolution of the Paraíba Basin, NE Brazil: a basic analysis using Sequence Stratigraphic Tool. In: AAPG ANNUAL MEETING, 2004, Dallas-Texas. Abstracts.... 2004.

BEURLEN, K . Estratigrafia da Faixa Sedimentar Costeira Recife - João Pessoa. Boletim da Sociedade Brasileira de Geologia, v. 16, n. 1, p. 43-56, 1967.

BEZERRA, F. H. R.; BRITO NEVES, B. B.; CORRÊA, A. C. B.; BARRETO, A. M. F.; SUGUIO, K. Late Pleistocene tectonic-geomorphological development within a passive margin: the Cariatá Trough, northeastern Brazil. Geomorphology, v. 97, n. 3-4, p. 555-582, 2008.

BEZERRA, F. H. R.; AMARO, F. R.; VITA-FINZI, C.; SAADI, A. Pliocene-Quaternary control of sedimentation 
and coastal plain morphology in NE Brazil. Journal of South American Earth-Science, v. 14, n. 1, p. 61-75, 2001.

BRITO NEVES, B. B.; ALBUQUERQUE, J. P. T.; COUTINHO, J. M. V. Estudo da Segmentação Tectônica da Sub-Bacia de Alhandra - PB. In: SIMPÓSIO DE GEOLOGIA DO NORDESTE, 22., 2007, Natal. Resumos... Natal: SBG, 2007, p. 219.

BRITO NEVES, B. B.; ARAUJO FILHO, J. C.; BEZERRA, F. H. R.; CORREA, A.; BARRETO, A. M. A Unidade Pedo-estratigráfica de Engenho Novo no Leste da Paraíba (Saliente Oriental Nordestino). In: SIMPÓSIO DE GEOLOGIA DO NORDESTE, 21., 2005, Recife. Resumos Expandidos... Recife: SBG, 2005a, p. 246-249.

BRITO NEVES, B. B.; FEITOSA, E. C.; BEZERRA, F. H. A Sub-Bacia de Alhandra (sul-sudeste da Paraíba) revisitada: contribuição de novos dados geológicos e geofísicos. In: SIMPOSIO DE GEOLOGIA DO NORDESTE, 21., 2005b, Recife. Resumos Expandidos... Recife: SBG, 2005b, p. 204-207.

BRITO NEVES, B. B.; MANTOVANI, M. S. M.; MORAES, C. F.; SIGOLO, J. B. As anomalias geológicas e geofísicas localizadas ao norte de Itapororoca (PB), folha Guarabira. Revista Brasileira de Geociências, v. 38, n. 1-23. 2008.

BRITO NEVES, B. B.; RICCOMINI, C.; FERNANDES, T. M. G.; SANT’ANA, L. G. O Sistema Tafrogênico Terciário do Saliente Oriental Nordestino na Paraíba: um legado Proterozóico. Revista Brasileira de Geociências, v. 34 , n. 1, p. 127-134, 2004.

CÓRDOBA, V. C.; JARDIM DE SÁ, E. F.; SOUZA, D. C.; ANTUNES, A . F.; MATOS, R. M. D. Nova Carta Estratigráfica para a Bacia Pernambuco-Paraíba. In: SIMPÓSIO GEOLOGIA DO NORDESTE, 22., 2007, Natal. Resumos.... Natal: SBG, 2007, p. 30.

COSTA. Consultoria De Serviços Técnicos E Ambientais Ltda. Estudo da Caracterização e verificação da Disponibilidade Hídrica da Vertente Litorânea do Estado da Paraíba: estudos hidrogeológicos. Recife: COSTA, 2007. 124 p. (Relatório final, tomo I, Anexo 1 - Cadastro de poços).

COUTINHO, J. M. V.; COIMBRA, A. M. Os pesados do Barreiras na costa oriental brasileira: estudo de áreas fonte. In: CONGRESSO BRASILEIRO DE GEOLOGIA, 27., 1973, Aracajú. Anais... . Aracajú: SBG, 1973, v. 1, p. 27-41.
CPRM . Companhia de Pesquisa de Recursos Minerais. Mapa geológico do estado da Paraíba. Recife: CPRM, 2002. 1 mapa, color. Escala 1:5000.000.

FEITOSA, E. C.; FEITOSA, F. A.; LIRA, H. M. P. Relações estratigráficas e estruturais entre a Bacia Potiguar e a Bacia Costeira PE/PB/RN, uma hipótese de trabalho. In: CONGRESSO BRASILEIRO DE ÁGUAS SUBTERRÂNEAS, 12., 2002, Florianópolis. Anais eletrônicos .... Florianópolis: ABAS, 2002. 1CD-ROM.

FURRIER, M .; ARAÚJO, M. E.; MENESES, L. F. Geomorfologia e tectônica da Formação Barreiras no Estado da Paraíba. Geologia USP. Serie Científica, v. 6, n. 2, p. 61-70, 2006.

LIMA FILHO, M F.; MELO, N. A . A Formação Barreiras na Paraíba, Pernambuco e parte de Alagoas: diferenças, evolução e origem. In: SIMPÓSIO DE GEOLOGIA DO NORDESTE, 22., 2007, Natal. Resumos .... Natal: SBG, 2007, p. 3.

LIMA FILHO, M. F.; BARBOSA, J. A .; SOUZA, E . M. Eventos Tectônicos e Sedimentares nas Bacias de Pernambuco e da Paraíba: implicações no quebramento de Gondwana e correlação com a Bacia do Rio Muni. Geociências. UNESP, v. 25, n. 1, p. 117-126, 2006.

OESA. Organização e Engenharia SA. Estudo de Reconhecimento e Estudo hidrogeológico para o aproveitamento integrado da Bacia potiguar e Bacias Costeiras da Paraíba e Pernambuco: estudos hidrogeológicos. Anexo Mapa Geológico 1/100 000. OESA, 1976. 228 p. (Relatório final MINTER/SUDENE/DRN através da CONESP, Companhia Nordestina de Sondagens e Perfurações).

SALVADOR, A. International Stratigraphic Guide: a guide to stratigraphic classification, terminology and procedure. 2nd. ed. Boulder: IUGS/GSA, 1994. 214 p.

SANTOS, E . J.; FERREIRA, C . A .; SILVA JUNIOR, J. M . Geologia e Recursos Minerais do Estado da Paraíba, escala 1/ 500 000: texto explicativo. Brasília: Superintendência Regional do Recife, 2002. 142 p.

SILVA, E. P. Mapeamento Gravimétrico e Cintilométrico das estruturas da Bacia paraíba (Parte Oriental) entre os paralelos de Pontas do Funil (PE) e Pitimbu (PB). 2006. 66 p. Relatório de Graduação. Curso de Geologia do Centro de Tecnologia da Universidade Federal de Pernambuco, Recife. 2006. 
SOUZA, E. M. Estratigrafia da Seqüência Clástica Inferior (Coniaciano-Maastrichtiano inferior) da Bacia da Paraíba: implicações paleogeográficas. 2006. 351 f. Tese (Doutorado) - Centro de Tecnologia e Geociências da Universidade Federal de Pernambuco, Recife, 2006.

TAVARES, J. R.; CORREIA, P. B. ; MOTTA, J. A . Mapeamento da Sub-Bacia Olinda e Sub-Bacia Alhandra-Miriri usando filtros espectrais e modelagem gravimétrica e magnetométrica.. In: CONGRESSO BRASILEIRO DE GEOLOGIA, 44., 2008, Curitiba. Anais... Curitiba: SBG, p. 851.2008. 
